\title{
CONTRACTARIANISM, CONTRACTUALISM, AND THE LAW OF CORPORATE INSOLVENCY
}

\author{
Rizwaan Jameel Mokal
}

\begin{abstract}
What is the appropriate way of theorising about corporate bankruptcy law? That lies, argues this paper, in rejecting Pareto and Kaldor-Hicks efficiency in favour of a particular conception of transaction cost efficiency, and in rejecting the 'contractarian' Creditors' Bargain Model in favour of the 'contractualist' Authentic Consent Model. The paper vindicates these arguments with an analysis of the automatic stay which characterises the collective liquidation regime, of the pari passu principle often said to be at the heart of this regime, and of the liability imposed in some jurisdictions on the managers of terminally distressed companies for failing to take reasonable steps to avoid further loss to their company's creditors.
\end{abstract}

\section{INTRODUCTION}

In a recent book, ${ }^{1}$ I argued that corporate insolvency law is most fruitfully analysed as that internally consistent set of principles which, both, fits and justifies most current legal texts and practices (together, 'legal practices') regulating what I called peculiar insolvency issues. These are issues uniquely associated with the situation in which an insolvent debtor is rendered unable to meets its obligations as they become due. Principles fit legal practices if and to the extent to which they cohere (in particular) with the letter and spirit of relevant statutes and with the reasoning and conclusions of relevant courts. And they justify these practices if and to the extent to which they show, both, that all the participants in those practices are treated as moral equals, and that the practices are structured so as to minimise the waste of social resources. ${ }^{2}$ In testing whether a particular principle respected the moral equality of all those subject to it, I employed the heuristic of asking whether each of them would be unable reasonably to reject its application to them in circumstances where none of them was aware of their personal circumstances, nor even of their own identity. ${ }^{3}$ And I argued in favour of a particular version of transaction cost efficiency as an appropriate means for investigating whether principles are wasteful. I labelled this methodology the Authentic Consent Model ('ACM'). The book employed the ACM to analyse some of the fundamental features of (English) insolvency law, including the moratorium on the enforcement of certain claims against insolvent companies ('the automatic stay'), the pari passu principle, ${ }^{4}$ the priority accorded by insolvency law to claims enjoying 'fixed' security, the nature of 'floating' security and of receivership, the new UK administration procedure, the

\footnotetext{
* Reader in Laws, University College London; Research Associate, Centre for Business Research, University of Cambridge; Barrister, 3-4 South Square, Gray's Inn, London. Thanks are due to Deborah Burns for timely assistance with typing.

1 Corporate Insolvency Law - Theory and Application (Oxford: Oxford University Press, 2005) ('Corporate Insolvency').

${ }^{2}$ The extent to which this approach is indebted to the work of Ronald Dworkin was acknowledged in the book's Preface, at v.

${ }^{3}$ The influence here of John Rawls, the most illuminating modern exponent of this approach, is obvious; see particularly Corporate Insolvency, 4-10 and 61 et seq.

${ }^{4}$ Which requires all those claimants classified as similar to each other under the general (non-insolvency) law to be treated alike in their debtor's insolvency.
} 
wrongful trading provisions, ${ }^{5}$ and certain provisions for the adjustment or reversal of preinsolvency transactions.

An interesting and thought-provoking review by Anthony Duggan ${ }^{6}$ provides an opportunity to revisit some of the book's central arguments. Duggan generously manages to find value in my work. ${ }^{7}$ He also, however, takes it to task, in particular, for claiming to have "reject[ed]" the Law and Economics methodology ${ }^{8}$ while nevertheless adhering to it "to a T"; 9 and for claiming to be different from the well-known Creditors' Bargain Model ('CBM') but in fact "eliding" this model with the $\mathrm{ACM}^{10}$ Drawing on these two themes, Duggan offers illuminating comments on my treatment of the automatic stay, the pari passu principle, the priority enjoyed under insolvency law by (fixed) secured credit, and the wrongful trading provisions. Perhaps his clearest substantive disagreements with me are as to whether the CBM can account for the automatic stay and for the wrongful trading provisions, ${ }^{11}$ and as to whether the ACM can reconcile the self-interest of relevant parties with that model's stipulation that each party comply with the requirements of what I called reciprocity. ${ }^{12}$ I consider these disagreements below. Virtually all of his other criticisms, as I read them, are directed not so much to the substance of or conclusions to my analysis ${ }^{13}$ but to the two methodological claims Duggan attributes to me, as highlighted above. ${ }^{14}$

It seems to me that Duggan is in many respects an ideal interlocutor. His commentary is greatly challenging, and forced me to rethink several key aspects of my work. Upon reflection, however, it turns out that almost all of his criticism is based on premises and propositions that I have quite explicitly considered, and rejected. Surprisingly, Duggan hardly ever engages with, let alone rebuts, the reasons I provide for such rejections. It follows that responding to him requires me to restate - and in some instances, develop - certain of my positions. These restatements are thus a convenient way of highlighting certain aspects of my approach to the analysis of corporate insolvency law which might be of some interest to a general corporate and commercial law audience. They also, I will argue, rebut Duggan's criticism.

\section{LAW, ECONOMICS, AND EFFICIENCY}

My work draws heavily on efficiency analysis. ${ }^{15}$ The conception of efficiency at play here is not, however, either of the ones common in much Law and Economics literature. In order to understand this point, a distinction must be drawn between what I call the substantive and the procedural goals of any part of the law.

\footnotetext{
${ }^{5}$ Explained below.

6 "Contractarianism and the Law of Corporate Insolvency” (2005) 42 CBLJ 463 (“"Contractarianism”').

7 "Contractarianism", 480-481.

8 "Contractarianism", 463 and 480.

9 "Contractarianism", 472.

10 "Contractarianism", 466.

11 "Contractarianism", 468-470 and 478-479, respectively.

12 "Contractarianism", 470-471.

13 Which is not to say that the conclusions always entirely persuade him; see for example "Contractarianism", 477 (apparent scepticism whether the existence of 'new money' secured credit is "universally value-enhancing").

${ }^{14}$ For reasons of space, I will not deal with Duggan's treatment of the priority of secured claims, but this should not be treated as implying that I accept his characterisation of my arguments.

${ }^{15}$ For a detailed elaboration of several of the arguments in this section and for a full citation of the sources on which they draw, see Corporate Insolvency, 20-26.
} 


\section{A. Substantive and Procedural Goals}

Substantive goals are those the pursuit by some part of the law of which confers ultimate justification on that branch of law by showing it in its best light, by demonstrating why it is valuable to have that body of doctrine and practice at all. 'To enable co-operation as moral equals amongst all those affected by peculiar insolvency issues' is an abstract statement of what I claim is the main substantive goal of insolvency law. It would be a compelling justification for the existence of this part of the legal domain, I have argued, that its absence would cause or lead to the violation of the right to equal concern and respect inherent in all those who come to face peculiar insolvency issues. Further and along parallel lines, certain fundamental principles of this law are justified to the extent to which they promote the moral equality of all those to whom they apply, and must be condemned to the extent that they detract from that equality. Procedural goals, by contrast, are ideals of the manner in which laws are implemented so as to attain substantive goals. To the extent to which social resources are scarce (and virtually all are), it is and must be a central procedural goal of any part of the legal system that it goes about implementing its substantive goals in the least wasteful manner practicable, since that would implement these substantive goals to the maximal degree.

I reject the Pareto and the Kaldor-Hicks versions of efficiency employed in most Law and Economics literature, on the basis that, inter alia, each purports to be, but is incapable of being, a substantive goal of the law. ${ }^{16}$

\section{B. The Untenability of Pareto and Kaldor-Hicks Analyses}

A transaction is Pareto-efficient if its occurrence satisfies the preferences of at least one person and does not cause a violation of the preferences of anyone else. Imagine the transfer of a resource $X$ from person A, who has a preference for retaining $X$ which he values at $£ 5$, to person $\mathrm{B}$, who has a preference for obtaining $X$ he values at $£ 10$. The transfer is Pareto efficient if $\mathrm{B}$ in fact fully compensates A for the loss of $X$ and is nevertheless better off, and if no one else is made worse off because of the transfer. It is Kaldor-Hicks efficient if (as is the case in our example) B could fully compensate A for the loss of $X$, and could also fully compensate anyone else made worse off because of the transfer, and still be better off, whether or not the compensation is in fact provided. ${ }^{17}$ Mainstream Law and Economics adheres sometimes to Pareto but mostly to Kaldor-Hicks efficiency. While 'positive' versions of this type of efficiency analysis claim 'merely' to be able to explain and predict the operation of the law by reference to what satisfies the most strongly valued preferences of those subject to (or sometimes, those formulating) the law, the 'normative' versions - which would be candidates for being substantive goals of the law - go further in asserting that fulfilling the most strongly valued preferences in this way confers legitimacy or normative justification on the law.

First, however, Pareto efficiency is virtually unattainable in the real world in even the most trivial transaction, since virtually any transaction inflicts uncompensated loss on at least some of those not party to the transaction, who are nevertheless interested either in the object of the transaction or in any of the substitutes or complements of that object. If and to the extent to

\footnotetext{
${ }^{16}$ It should be noted that the criticisms to follow hold equally of the notion of 'welfare' recently touted by some Law and Economics scholars as an improvement upon 'efficiency' as an analytical tool and/or moral norm; see for example the persuasive arguments made by Jules Coleman, "The Grounds of Welfare" (2003), 112 Yale LJ 1511. See also the somewhat differently-oriented argument in Matthew Adler and Eric Posner, New Foundations of Cost-Benefit Analysis (London: Harvard University Press, 2006).

${ }^{17}$ This explains why Kaldor-Hicks efficiency is sometimes referred to as 'potential' Pareto efficiency.
} 
which we desire our substantive goals to be practicably realisable, we must reject Pareto efficiency as a substantive goal of the law. Secondly, given that virtually no transaction meets the demanding conditions of Pareto efficiency, whatever distribution of resources exists at any given time is also Pareto-optimal, and any move away from that distribution (for example, any transaction involving the exchange of assets or entitlements) is Pareto inefficient. ${ }^{18}$ The pursuit of Pareto efficiency is therefore a recipe for stasis!

Thirdly, Kaldor-Hicks efficiency is normatively odious because it claims justification for the uncompensated-for infliction of even horrendous harm to or expensive losses on some, as long as a sufficiently large number of others thereby gain benefits for which each of them has even a trivial individual preference. Taking a staple example, it is Kaldor-Hicks efficient to inflict on a minority group some harm (say, legalised discrimination in the provision of jobs and housing) to which this minority group would strongly prefer not to be subject, so long as there is a sufficiently large majority group each of whose members has (even) a small individual preference (based, let us assume, on prejudice of some sort) for the infliction of that harm which cumulatively exceeds the dispreference of the minority. If and to the extent to which we consider this outcome normatively unattractive, ${ }^{19}$ we must reject Kaldor-Hicks efficiency as a substantive goal of the law.

Fourth and interestingly, if and to the extent to which some individuals have a sufficiently strong preference against the infliction of either uncompensated harm of the sort I have just sketched out or other uncompensated losses, Kaldor-Hicks efficiency becomes increasingly unlikely to be achieved. Indeed, this type of efficiency becomes impossible to attain if there is just one person with such a strong preference against the infliction of non-consensual losses on himself or others (that is, to the likely consequences of the implementation of KaldorHicks efficiency itself) that no amount of ex post compensation would suffice to make him as well off as he would be in the absence of the infliction of those non-consensual losses! ${ }^{20}$

Fifth and in any case, both these versions of efficiency are indeterminate, since each of them is susceptible to income, wealth and endowment effects (together, 'wealth effects'). The precise nature of one's preferences and the degree to which one values them are both functions of, inter alia, one's income and wealth. It follows that an alteration in the distribution of income or wealth would lead, in any given situation, to an alteration in the demands made by both Pareto and Kaldor-Hicks efficiency. For example, consider the sole supply of a rare hormone which can either be employed so as to confer an extra couple of centimetres of height on a child $\mathrm{C}$ who is blessed with very rich parents able and willing to outbid anyone else for the hormone, or can save the life of a child D who must make do with very poor parents. ${ }^{21}$ Efficiency of either sort would be achieved by ensuring that the hormone goes to $C$, thus satisfying the higher valued preferences of C's parents. The fact that such an outcome would be recommended by efficiency analysis, regardless of the intrinsic worth of the competing potential uses, might itself be regarded as

\footnotetext{
${ }^{18}$ See for example Guido Calabresi and Philip Bobbit, Tragic Choices (New York: Norton, 1978), 83-87; see also Corporate Insolvency, 21-23, including the footnotes. Guido Calabresi is one of the 'Four Fathers' of Law and Economics, along with Ronald Coase, Richard Posner, and (depending on who is consulted about this paternity) Gary Becker or Oliver Williamson.

${ }^{19}$ At the very least, it would be a necessary condition for the justifiability of the infliction of this harm that it resulted from a process which had accorded equal care and concern to certain fundamental interests of all of those affected, including and particularly those who would be harmed. See further the sixth point discussed below.

${ }^{20}$ See in particular Jules Coleman, Markets, Morals and the Law (Cambridge: Cambridge University Press, 1988), 138.

${ }^{21}$ This example derives from Ronald Dworkin, "Is Wealth a Value?" (1980), J. Legal Studies 191.
} 
presumptively objectionable on moral grounds. In any case, however, if wealth had been differently distributed such that D's parents were able and willing to outbid C's, efficiency would demand that $D$ received the hormone. It follows that unless we can be assured that the initial distribution of (in this case) wealth is itself justified, there is no reason for thinking that satisfying the strongest preferences produced by (among other things) that distribution of wealth would confer any justification at all on whatever mechanism brought about that preference satisfaction.

What is more, it would be equally consistent with this type of efficiency analysis to alter the initial distribution of wealth rather than satisfying the preferences created (inter alia) by that distribution. To go back to the example of rich $\mathrm{C}$ and poor $\mathrm{D}$, it would be as Pareto or KaldorHicks efficient to redistribute the wealth of C's parents to D, and then to meet the then-stronger preferences for the hormone of D's parents, as to leave the initial distribution of wealth unaltered and to meet the originally-stronger preferences of C's parents. There is nothing in this type of efficiency analysis to recommend satisfaction of the set of preferences existing in one state of affairs (here, wealthy $\mathrm{C}$ family/poor $\mathrm{D}$ family) over the very different ones that would exist if that state of affairs were itself to be altered (poor C family/wealthy D family). Hence (once again) the indeterminacy. $^{22}$

Sixth and finally on this point, claims of the sort underlying mainstream 'normative' Law and Economics that the satisfaction of preferences (in one of the two ways explored above) is the dominant, or even the exclusive, method for conferring legitimacy on the law are inherently implausible, since they fail to distinguish between those aspects of life which we have reason to shape in accordance with our preferences, and those aspects of life where we have reason to shape our preferences in recognition of preference-independent values. ${ }^{23}$ To the extent to which someone enjoys collecting stamps and has a preference for devoting some of his time to this activity, this fact confers value (at least presumptively) on the time he spends doing so. Put differently, the stamp collector has a valid reason, stemming (in part) from his preference for his hobby, to dedicate some of his life to this activity. ${ }^{24}$ Correspondingly, a legal system which enabled him to pursue his hobby (for example, by providing appropriate rules of contract and property) would be justifiable for that reason. Suppose, however, that the stamp collector also has a preference for torturing small animals or abusing people of a particular sexual orientation. The fact of his preference, no matter how strongly held, would confer no legitimacy on a system

\footnotetext{
${ }^{22}$ It would be incoherent at this point to raise any objections to the redistribution based on its 'costs'. The determination that a particular state of affairs counts as a 'cost' is in this context itself a product of efficiency analysis; see R. Mokal, "On Fairness and Efficiency" (2003), 66(3) MLR 452 ("“Fairness and Efficiency"'), 458. It follows that what counts as a 'cost' by reference to the parties' preferences prior and subsequent to the redistribution could be expected to differ. Prior to the redistribution, those who would lose from it would be likely to have a more strongly valued preference against the redistribution, whereas subsequent to the redistribution, those who had gained from it would be likely to have a more strongly valued preference for the resulting state of affairs! Echoing the point in the text, there is nothing in this sort of efficiency analysis to indicate why the preferences which are the product of one distribution of resources should be privileged over those the product of a different distribution. For a similar point, see Jules Coleman, "The Grounds of Welfare" (2003), 112 Yale LJ 1511, 1518-1519.

${ }^{23}$ For a comprehensive examination of this and related issues, see Ronald Dworkin, "Equality of Welfare", chapter 1 in his Sovereign Virtue - The Theory and Practice of Equality (Cambridge MA: Harvard University Press, 2000).

${ }^{24}$ This is for the deeper moral and ethical reason that preference satisfaction is one means by which the (preference-independent) values of autonomy, liberty and self-government are pursued. For an argument exploring the connection between some such values on the one hand and 'idealised' or 'laundered' preferences on the other, see Matthew Adler and Eric Posner, New Foundations of Cost-Benefit Analysis (London: Harvard University Press, 2006), particularly chapter 6.
} 
which allowed him to indulge in these activities. Nor would a system allowing the torture of small animals or the heaping of abuse on members of a particular group gain in legitimacy because more and more people developed strongly held preferences for these activities. ${ }^{25}$ Instead, the legal system would be morally justified in attempting to alter, or at least repress, the expression of, these morally objectionable preferences. There are direct ethical analogues to this moral point. ${ }^{26}$ Suppose the stamp collector has no preference for engaging in any other forms of play, ${ }^{27}$ or for the pursuit of friendships (even, let us assume, with members of his family), or the acquisition of knowledge, or the appreciation of art. Nevertheless, in the case of each of these goods, he has valid reasons (whether he recognises them or not) for altering his preferences. His life goes better if he does participate in some or more of these goods in some appropriate manner, and is impoverished if he does not, other things being equal. ${ }^{28}$ In neither the moral nor the ethical domain, then, would an absence on its subjects' part of a preference for something (preferenceindependently) valuable or a preference for something (preference-independently) wrong shield the legal system from moral condemnation or ethical reproach (as appropriate).

To reiterate this hugely abbreviated and simplified point: The fact that a set of legal standards contributes to the satisfaction of (even strongly held) preferences confers normative value upon that set - justifies it - if but only if those standards do not cause or enable a violation of the fundamental moral rights of any of those affected by them, and do not encourage (or at least, do not necessitate) the making of ethically perverse choices by them. It follows that any approach, including any version of 'normative' Law and Economics, which claims for efficiency (that is, for some form of preference satisfaction) the status of the exclusive or even dominant substantive goal of the law, violates these crucial moral constraints and therefore must be rejected.

\section{The Role of Transaction Cost Efficiency}

For these sorts of reasons, then, I reject Pareto and Kaldor-Hicks efficiency as inappropriate to legal analysis. I certainly do not, however, contra Duggan, "reject law and economics", in favour of either "a Rawlsian approach" or "an egalitarian perspective". ${ }^{29}$ I must admit to being puzzled

\footnotetext{
${ }^{25}$ If anything, the system might become increasingly deserving of ever stronger moral condemnation if it was contributing to the perversion in this way of its subjects' preferences.

${ }^{26}$ Moral philosophy literature often distinguishes between the moral, which governs how an agent must behave with respect to others, and the ethical, which is about what for that agent would constitute a good life.

${ }^{27}$ Which here means something engaged in simply for its own sake.

${ }^{28}$ As to this list and as to the basic claim barely outlined in the text here, see for example John Finnis, Natural Law and Natural Rights (Oxford: Oxford University Press, 1980).

${ }^{29}$ See "Contractarianism", 463 (without any citation of my work) and 480 (citing Corporate Insolvency, vi) respectively. Duggan's reading here is perhaps less careful than one might have hoped for: what I said (at vi) I had come to reject was the "fairly mainstream version of Law and Economics" that I had espoused before becoming familiar with Ronald Dworkin's (and others') arguments. More specifically, I used to adhere to Richard Posner's views about Law and Economics before I came across the debates the effect of which is captured by Daniel Farber and Brett McDonnell in the following colourful (though, given recent events elsewhere in the world, perhaps unfortunate) way: Posner "got his head handed to him on a plate by a variety of critics, most notably Ronald Dworkin"; see Farber and McDonnell, "Why (and How) Fairness Matters at the IP/Antitrust Interface" (2003), 87 Minnesota LR 1817, 1822. My rejection of this particular school of Law and Economics does not necessitate that I eschew economic analysis altogether, as demonstrated by the arguments in this section. It should be noted that Duggan is not entirely consistent in the views he attributes to me. On "Contractarianism", 480, a couple of sentences after asserting that I
} 
that Duggan thinks otherwise, when, for example, six pages in my book's introductory chapter are dedicated to explaining exactly what role efficiency plays in the argument, ${ }^{30}$ and when even the book's dust jacket records my claim that the ACM "can reconcile the dictates of fairness with the demands of economic efficiency".

Instead, as I took pains to explain in the book, ${ }^{31}$ while:

"efficiency can never be a substantive goal of the law[, and thus, while it] can never by itself confer justification on any part of it, [] efficiency - understood properly - is quite indispensable as a procedural goal. Once a set of substantive goals has been exogenously specified (e.g. using a theory of justice), efficiency can be used to judge between various proposed schemes for implementing it." 32

The procedural version of efficiency which I defend, drawing on the literature on transaction cost economics, requires that a set of substantive goals be implemented in such a way that the process of implementation would consume fewer resources than would be used up by adopting any other feasible method of implementation. Or to put it another way, given a particular amount of resources dedicated towards the implementation of a set of substantive goals, efficiency results when those goals are operationalised to a greater degree than would be possible by adopting any other feasible method.

Transaction cost efficiency aims to minimise two types of cost. Co-ordination costs are the costs arising from the fact that there are limits on what people in the real world can foresee, and on their cognitive capacity for selecting the appropriate response to a set of circumstances presented to them. These costs also arise because there are informational asymmetries, e.g. information relevant to the common plans of both A and B is available only to the former, or is available to him to a greater degree than to the latter. The implication, given the aim of implementing any set of substantive goals requiring co-operation, is that some resources would have to be expended either ensuring that information is available to a fuller and more uniform degree to all the relevant actors, or that the adverse effects of this not being the case are remedied. Motivation costs arise because different actors, perceiving their interests not to lie in the same direction, have different incentives about how to behave in any situation. Again given the aim of implementing a set of substantive goals requiring co-operation, some resources would have to be expended aligning their interests in such a way that the actors would be encouraged to pursue those goals.

\section{The Relationship between Egalitarianism and Efficiency}

It should be clear, then, that in my work, efficiency analysis is not forsaken in favour of "a Rawlsian approach" or "an egalitarian perspective". Rather, an egalitarian theory of insolvency law is drawn upon to specify the substantive goals of this law, and in addition, a particular version of efficiency is deployed to assess whether the law goes about implementing those substantive goals in a way that minimises waste.

"reject law and economics", he attributes to me the more accurate claim that my work "subordinates efficiency to egalitarianism".

${ }^{30}$ Corporate Insolvency, 20-26. At "Contractarianism", 466, Duggan cites the opening part of this discussion - headed "Some comments on the role of efficiency" - but, mysteriously, is persuaded that this is further evidence of my attempts surreptitiously to embrace efficiency analysis while claiming to reject it.

${ }^{31}$ See also "Fairness and Efficiency", particularly 454-462.

${ }^{32}$ Corporate Insolvency, 25 (emphasis altered). 
I hope that this discussion will go some way towards resolving the mystery with which Duggan appears to be grappling during much of his review. Time and time again, he stresses, with something of an air of discovery and as if this were a point against me, that "the methodology Mokal employs...is essentially an economic one... and he draws heavily on the economics and law and economics literature", ${ }^{33}$ that "efficiency is the driving consideration" in my argument, ${ }^{34}$ that my reasoning is "essentially economic [in] nature". ${ }^{35}$ Well, so it is (at least on most of the points highlighted by Duggan), as long as one remembers the precise nature of the efficiency at play and also its subordinate and merely instrumental role vis-à-vis the egalitarian requirements of justice and fairness. I warned in the book ${ }^{36}$ that much Law and Economics literature is confused because methodologically self-unaware, moving indiscriminately between Pareto, Kaldor-Hicks and other versions of efficiency without realising it and without understanding the implications of the differences between these versions, in particular, that the first two purport (in my terminology) to be substantive goals of the law while some others can only be procedural goals. In failing even to acknowledge my discussion of different versions of efficiency, Duggan appears either to have overlooked these warnings, or at least implicitly, is not persuaded that they pertain to a real danger of confusion. The latter position is in any case invalidated by the nature of at least some of his own commentary.

Be that as it may, it seems to me that in order to make an argument against me on this territory, Duggan would have to show not merely that I draw on economics or that my conclusions would not offend "even the most ardent of free enterprise proponents", ${ }^{37}$ but that I mistakenly draw on one or other of the versions of efficiency I have condemned, or that I lose sight of the primacy of the demands of justice in my eagerness to embrace economics. While I might yet be liable to criticism on such grounds, Duggan's review, as I read it, provides little reason for thinking so.

\section{THE CREDITORS' BARGAIN AND THE AUTOMATIC STAY}

The CBM, as propounded by Thomas Jackson, sometimes in collaboration with Robert Scott and Douglas Baird, claims to be able to elucidate the deep structure of corporate insolvency law and to assess its normative validity by reference to the preferences it claims would be expressed by creditors ex ante, before any lending has taken place, and thus, well before the debtor has become insolvent: ${ }^{38}$

33 "Contractarianism", 471.

${ }^{34}$ Ibid., 477.

${ }^{35}$ Ibid., 479.

${ }^{36}$ Corporate Insolvency, 20-21, 24 n. 95 and 26 n. 99; see also "Fairness and Efficiency".

37 "Contractarianism", 480. Other things being equal, the greater the proportion of readers who do not "take issue with [my] policy prescriptions" (ibid.), the better for me, I would have thought. If, on the other hand, Duggan intended to imply that egalitarians of some description would take issue with some of my policy prescriptions, I wish he had said so, in which case his reasons for taking that view would no doubt have been instructive.

${ }^{38}$ See e.g. Thomas Jackson, Logic and Limits of Bankruptcy Law (Cambridge MA: Harvard University press, 1986) ('Logic and Limits'). For a comprehensive account of the arguments in this section and a detailed citation of sources, see Corporate Insolvency, chapter 2. 
"[The CBM] views bankruptcy as a system designed to mirror the agreement one would expect the creditors to form among themselves were they able to negotiate such an agreement from an ex ante perspective". ${ }^{39}$

\section{A. The Supposed Operation of the CBM}

The CBM's explanation of the automatic stay is supposedly emblematic of the model's methodology. Why does corporate insolvency law impose a moratorium on the enforcement of claims against an insolvent company? Because, replies the CBM, this is precisely what would have been agreed to by all the creditors of that company, if only they could costlessly bargain together ex ante.

The pre-insolvency method for debt collection is individualistic: in general, a creditor is paid as and when its claim matures and it chooses to press it. The creditors of a common solvent debtor have nothing to fear from each other since there is, by definition, sufficient value in the debtor's estate to satisfy them all.

Creditors bargaining ex ante anticipate, however, that all this would change if and when doubts were to arise about the debtor's solvency. By definition, an insolvent debtor would be unable to meet all its liabilities in full. In that case, there would be a premium on 'racing' to enforce claims: the earlier that a particular creditor could press its claim, the more likely it would be to be paid in full, or at all. The tardy creditor could find itself with nothing, the debtor's bones having been picked dry by fellow claimants who had managed to swoop faster. Ex ante, all creditors would regard this as problematic. First, some of them are likely to be risk-averse, and would thus prefer a lower but more certain return on their prospective loan than the higher but riskier one offered by the individualistic pre-insolvency collection method. Secondly, each of them would have some incentive to monitor the debtor for the earliest signs of distress in order most favourably to position themselves for the ensuing race. Much of the expenditure incurred by the creditors as a group would, however, be necessarily duplicative and inefficacious. Regardless of the aggregate of this expenditure, some of them would still be left with little or nothing in their debtor's insolvency. And thirdly, the debtor might merely be financially (and not economically) distressed, so that its assets would be worth more if kept together as a going concern than they would be if stripped from its business and sold off piecemeal. Nevertheless, if the only method for the enforcement of claims were the individualistic pre-insolvency one, the debtor would be required to meet claims one by one, as they were enforced. This would be likely to precipitate the dismantling of the business, leading to the loss of any 'going concern surplus'.

Bargaining ex ante, all the creditors would thus come to the conclusion that it would be in the self-interest of each of them that they gave up their individualistic debt collection rights in return for the entitlement to participate in a collective enforcement proceeding against the insolvent debtor. In this collective forum, any going concern surplus would be preserved by making a once-and-for-all decision on behalf of all creditors about the value maximising manner of disposing of the debtor's business. The need to incur duplicative monitoring costs would be mitigated because claims would be met in a rational and orderly fashion, and not merely in the order in which they were brought. And for the same reason, risk-averse creditors would be assured a more certain if lower return within the collective forum than they would expect if left to fend for themselves under the individualistic system. The collective regime characterised by the automatic stay merely duplicates the effects of this hypothetical ex ante bargain, asserts the CBM,

${ }^{39}$ Thomas Jackson, "Bankruptcy, Non-Bankruptcy Entitlements, and the Creditors' Bargain" (1982), 91 Yale LJ 857 ('Jackson, "Bankruptcy"), 860-861, as cited by Duggan, "Contractarianism”, 463-4 and 467. 
thus eliminating the costs that real-life creditors would have to incur trying in fact to negotiate a moratorium on claims in anticipation of the possibility of their mutual debtor's insolvency.

I accept that the need to mitigate risk-aversion, to control duplicative monitoring costs, to preserve any going concern surplus, and to eliminate the need for factual ex ante bargains, all are relevant considerations in attempting to understand and justify the automatic stay. I deny, however, that the $C B M$ can account for them, or for the automatic stay, or for any other aspect of insolvency law, in anything like the manner described above, or in any other coherent manner. In order to vindicate this apparently harsh judgement, and so as to address Duggan's observations, I will focus in the following sub-sections on some of the basic building blocks of the CBM. ${ }^{40}$

\section{B. 'Agreement' in the Hypothetical Bargain}

How does the CBM go about identifying the propositions to which it claims all the relevant creditors would have agreed? And what is the nature of this hypothetical agreement? While answering these questions merely requires making explicit what is implicit in the discussion thus far, the results might nevertheless surprise those tempted by the model's explanation of the automatic stay.

Note first of all that the CBM, as a member of a family of theories based in classical microeconomics, claims that while each relevant creditor $^{41}$ pursues nothing except its own interests, that the product of this pursuit is, nevertheless, the collectively desirable state of efficiency. ${ }^{42}$ Recall the point made in the previous section of this paper, that those writing in the Law and Economics tradition are often methodologically unself-conscious, frequently do not appreciate the (analytical, let alone moral) significance of the distinction between Pareto, KaldorHicks, and other forms of efficiency, and often switch between versions as if the differences did not matter. The progenitors of the CBM are good exemplars of these tendencies. They are usually not explicit about the nature of the efficiency analysis which they deploy. When minded to make their position explicit, however, they rely usually on Kaldor-Hicks, ${ }^{43}$ and less often, on Pareto. ${ }^{44}$

We reach the same conclusion about the CBM's exclusive focus upon the individual selfinterest of each creditor from a different (and independently instructive) direction. When the CBM claims creditors consulted ex ante would consent to certain provisions, how does it ascertain what those provisions would be? No actual consent has expressly been given to any such provisions; that is precisely why resort must be had to an hypothetical agreement. Nor is there any actual unexpressed consent, that is, consent present (as it were) in the minds of all the relevant creditors even if not made explicit by them. Creditors come in many varieties, many of

\footnotetext{
${ }^{40}$ For detailed textual and substantive support for the arguments that follow, see Corporate Insolvency, chapter 2 . Only a quick summary can be provided here.

${ }^{41}$ That is, each creditor $\mathrm{X}$ of whom each of the following propositions is true: (i) $\mathrm{X}$ would be driven by its self-interest into the hypothetical agreement, and, (ii) each other creditor, again driven by their respective interests, would accept X into that agreement. More than once, Duggan appears to have overlooked the second of these necessary conditions; see for example the discussion of tort creditors, below, and of C1, C2 and $\mathrm{C} 2$, further below.

${ }^{42}$ While it is difficult to prove a negative, the reader is invited to consult the writings of the CBM's progenitors to confirm that they do not attribute to creditors any motivation except individual self-interest. For further explanation and for an outline of the intellectual antecedents of the CBM in the work of Richard Posner, see Corporate Insolvency, 36 and 40-47; note also to whom Logic and Limits is dedicated, at v.

${ }^{43}$ See for example Jackson, "Bankruptcy", 870, footnote 61; and Robert Scott, "The Truth About Secured Financing" (1997), 82 Cornell LR 1436.

${ }^{44}$ See for example Jackson, "Bankruptcy", 874, footnote 78.
} 
whom (for example, most employees, consumer pre-payers, many trade creditors, to say nothing of any tort claimants) would not even realise that they were classified by law as creditors, and even if they did, would have no idea of how they would be treated in their debtor's insolvency. Therefore, any suggestion that such creditors have in fact given some sort of actual, even if unexpressed, consent to the stay would be incredible. In any case, the CBM provides no evidence whatsoever to this effect.

What about reconstructed consent, then? This is the sort attributed to the parties to a contract in circumstances where a term is to be implied in the contract, on the basis that a reasonable person in their shoes would have consented to the inclusion of that term. But this does not help either. Reconstructed consent is usually presumptive (a term will not be implied where the contract explicitly provides to the contrary) and so cannot be invoked with respect to a compulsory legal standard (the automatic stay would apply even if an unsecured creditor had lent to the debtor expressly subject to the condition that the former would be immune from the stay in the latter's insolvency). Further, reconstructed consent with respect to an implied term can be attributed to the parties only because they have actually consented to entry into the contract. ${ }^{45}$ In more general terms, it is only when a person has given actual consent to his participation in a particular institution (in our example just now, contract) that it is permissible to attribute reconstructed consent to him with respect to a particular feature of that institution (in our example, a particular implied term). However, the CBM must, and claims to be able to, justify subjecting the parties to the coercion inherent in insolvency law in the first place, and in particular, that underlying the automatic stay. So it can not, if it is to avoid begging the question, have recourse to the sort of consent which would be regarded as having come into existence only because, and by virtue of, the creditors actually having consented to the application to them of insolvency law. And finally on reconstructed consent, the 'reasonable person' is regarded as having consented to the term in question only because there are consideration quite independent of consent which make it reasonable to conclude that the parties would have accepted that term. Without an adequate account of those consent-independent considerations, therefore, the argument from reconstructed consent would not even get off the ground.

This brings us to counterfactual consent, which, as the label indicates, is consent the parties have never in fact given. This label usefully reminds us that such consent can be attributed to someone only at the conclusion of the argument, that is, only when the person wishing to make the attribution has explained why he considers it reasonable to suppose that consent would have been given, even though it never in fact was. This is precisely the form of consent at play in the $\mathrm{CBM}$, and the only reason in favour of attribution offered by that model's progenitors - the only reason their model has the resources to provide - is that some or other aspect of insolvency law (in our example, the automatic stay) is in the independent self-interest of each (relevant) creditor.

So the CBM draws on standard efficiency analysis (of the sort described in the previous section) to claim that if consulted ex ante, each creditor, driven by self-interest, would have expressed a preference for the automatic stay. The stay is justified because it is Kaldor-Hicks, or perhaps, Pareto, efficient.

This highlights the first set of problems for the CBM. If the move from the individualistic to the collective regime is Pareto efficient, then each relevant creditor (if conceived of, problematically, as driven by their self-interest alone) could plausibly be regarded as having consented to it. However, this simply does not hold if the move is merely Kaldor-Hicks (but not

${ }^{45}$ See for example Anne de Moor, "Intention in the Law of Contract: Elusive or Illusory?" (1990), 106 LQR 632. 
Pareto) efficient. Suppose some creditors (each driven by their individual self-interest alone) would be better off under the individualistic regime than under the collective one. ${ }^{46}$ Such creditors obviously have no reason to prefer the latter to the former simply on the basis that their competitors (that is, creditors who would be better off under the collective regime than the individualistic one) could have compensated them for the individualistic-to-collective move though in fact did not do so. No hypothetical agreement in support of any rule or policy can be manufactured out of an argument that that rule or policy is Kaldor-Hicks (but not Pareto) efficient. ${ }^{47}$ It follows that unless the CBM can show that the automatic stay is Pareto efficient, it must abandon any claim that the stay would have attracted the consent of all the relevant creditors.

Secondly, however, and keeping in mind the discussion in the previous section of this paper, why should we care whether or not the automatic stay results in Pareto or Kaldor-Hicks efficiency? After all, these forms of efficiency are both question-begging and indeterminate because susceptible to wealth effects, and Kaldor-Hicks in particular is normatively odious. So even if the CBM were (though as we shall see, it is not) able to demonstrate that either form of efficiency would be achieved upon the implementation of the stay, that would confer no justification on it, for the reasons discussed above. ${ }^{48}$

Let us turn to the third set of issues for the model, which I will raise here and consider after having discussed certain other elements of the CBM. Note that self-interest is a function of knowledge: It would, for example, be in the interests of a risk-preferring punter to buy a ticket in a fair lottery if his interest is reckoned ex ante, before the lottery has taken place (or at something of a stretch, before he has discovered the result of the lottery). Buying the ticket would not be in his interests ex post, that is, if it is already known that the ticket in question has lost. This is a perfectly general point: buying home insurance is in your interests if you do not know whether or not your home will burn down. It might not be in your interests, however, if you somehow have perfectly reliable knowledge that your home will never burn down. Correspondingly, selling you insurance is in the interests of the insurance company if it is not known whether or not your home will burn down, but might not be in its interests if it is known with perfect certainty that your home will burn down. And so on. The CBM relies on the self-interest of each (relevant) creditor in asserting that each of them would have agreed in the ex ante hypothetical bargain to the imposition upon them of the automatic stay. Obviously, therefore, it must specify with sufficient precision exactly when, ex ante, this bargain supposedly takes place. Does it?

Further, recall again that the CBM would regard a particular creditor $\mathrm{X}$ as having given consent to the automatic stay if, and to the extent to which, the stay would be in X's self-interest. However, X's self-interest is likely to shift from time to time. It follows that the propositions to which it could be considered to have consented would also change accordingly. To illustrate this point, suppose that at time $t 1, X$ is a weak, over-stretched trade creditor. It anticipates being unable to spend much on monitoring its debtor and racing for its assets, should the debtor become

\footnotetext{
${ }^{46}$ As is indeed the case; see below.

${ }^{47}$ See further Ronald Dworkin, "Why Efficiency?" (1980), 8 Hofstra LR 563.

${ }^{48}$ The foregoing discussion also suggests that Duggan, "Contractarianism", 471, is mistaken in suggesting that the CBM attaches merely predictive, but no normative, significance to the assumption that creditors are motivated by their respective self-interest. The model takes the maximal satisfaction of self-interested preferences to be its sole source of justification. It is not so much that the CBM asserts that the creditors ought to be motivated by self-interest, more that it has no resources for conceiving of what else there is that might motivate them. This point, explained at some length in Corporate Insolvency, chapters 2 and 3, particularly 87-90, relates to the fundamental reason why the 'contractarian' CBM differs from the 'contractualist' ACM.
} 
financially distressed. $X$ also expects there to be other, better-resourced creditors who would beat it in any such individualistic race. When consulted at this time, therefore, suppose that $\mathrm{X}$ indicates consent to the automatic stay, on the basis that it would be in its self-interest to neutralise the individualistic advantages of its better-resourced competitors. At a later time $\mathrm{t} 2$, however, $\mathrm{X}$, having made a succession of profitable deals, finds plenty of resources at its disposal to expend on monitoring any prospective debtors. It now states that it wishes to change its choice, opting to remain subject to the individualistic regime in the expectation that it could beat most of its rivals in most races it might run to collect debts under the individualistic regime. ${ }^{49}$ Should $\mathrm{X}$ be allowed to resile from its actual consent? Note that if this question is answered in the affirmative, then the similar question premised on X's implied consent must a fortiori be answered in the affirmative. If actual consent in such circumstances does not bind, nor would any variety of implied consent. ${ }^{50}$

So, is X's change of mind condemnable, because normatively suspect in some way? This depends on the sort of choice $\mathrm{X}$ was asked to make. If what was required of it was merely an expression of its preferences, as is the case within the CBM, then there is nothing objectionable in changing one's preferences in line with one's self-interest. It would be perfectly permissible indeed, more accurate - to say that X prefers the collective regime marked by the automatic stay up until time $\mathrm{t} 2$, and the individualistic regime thereafter. It would be another matter if $X$ had been asked to pick what it regarded as the fair or just rule (or even the most economically efficient one). Its change of mind would then smack of hypocrisy. But under the CBM, the only question to which $\mathrm{X}$ can be regarded as having given an answer is simply what is in its selfinterest.

It would be no answer to say here that the choice made before time $t 2$ would have encouraged legitimate expectations about how future transactions would be dealt with, so it should be held binding. Remember that the order of choices is arbitrary and could be reversed (a rich creditor which had chosen the individualistic regime before $\mathrm{t} 2$ is newly-impoverished and only now wishes to choose the collective one). In that case, the CBM would insist upon the legal reification of the choice for the individualistic regime, hence providing no support for our collective system. Or it might be stipulated that the choice made at $t 2$ should only affect transactions taking place at later times $\mathrm{t} 3, \mathrm{t} 4$, etc. Since there would then be no retroactivity, there could be no confounded expectations, and the automatic stay could be abandoned thenceforth for the free-for-all system.

Now of course a legal system can not allow its insolvency rules to change in line with the whims of one or other creditor. To say that, however, is not to support but to condemn the CBM. There is nothing in that model itself which weaves together non-binding preferences into binding rules. In the example above, the model can not explain why X's preference for the collective regime should be considered as overriding its later preference for the individualistic regime (or indeed vice versa). So the model provides no justification for the coercion inherent in the collective regime. Nor, as noted, can it be any response at all that the preferences with which the CBM is concerned are "implied", not real. If one's real choices do not bind, then why should

\footnotetext{
${ }^{49} \mathrm{X}$ does not require a "sure way of knowing that it will have the same advantage over other creditors in all future cases", contra Duggan, "Contractarianism", 468 (emphasis added). The individualistic regime is in its interests so long as its net expected returns from winning a proportion of races (taking into account the expected costs of losing the others) under the individualistic regime is greater than the expected returns from participation in the collective regime. X's example is set up precisely so as to suggest that at time t2, this cost/benefit analysis favours X's remaining under the individualistic regime.

${ }^{50}$ For a similar argument, see Daniel Brudney, "Hypothetical Consent and Moral Force" (1991), 10 Law and Philosophy 235, 238-239.
} 
choices that one never actually made? And crucially, there are no substantive or procedural constraints in the model to ensure that the rules picked (actually or counterfactually) would be considered binding.

Here, then, are some of the challenges that the CBM must meet. In determining whether the automatic stay would have been consented to, exactly when is the self-interest of each of the creditors to be measured? And what makes that point privileged, so that even mere preferences shaped by self-interest alone, if expressed at that time, ought to be considered binding, contrary to the import of the argument I just outlined?

As we move to the next part of the discussion, however, the reader should be aware that while the points I have just highlighted were all considered in great detail in the book, as were their implications for the CBM, Duggan does not even advert, let alone respond, to any of them in his review, even when he outlines and defends what he considers to be a different, more tenable version of the CBM. As we will see, that leaves Duggan's preferred form of the CBM open to precisely the criticisms that I levelled against the 'standard' forms of that model (even assuming for the moment that Duggan has identified a variant on those standard forms).

\section{The Real Parties Premise and Imaginary 'Creditors'}

It is important to note that the CBM is supposedly based on the hypothetical consent of the actual creditors who would come to be affected by corporate insolvency law, and for the purposes of our example, by the automatic stay:

"[The] hypothetical bargain analysis provides indirect evidence of what real world parties would, in fact, agree to." 51

This 'Real Parties premise' implies that the various bargainers are (and as we will see below, know that they are) secured or unsecured, ${ }^{52}$ that some are "systematically faster... or friendlier with Debtor" than others, ${ }^{53}$ and that they are able to affect the (notional) bargaining process differently according to their "relative savvy and bargaining skills". 54

It is important to understand that without the Real Parties premise, nothing would be left of the CBM. In its justificatory role, this model is supposed to legitimate the real-life coercion inherent in the automatic stay against real-life creditors (they are deprived of the freedom of action and any other advantages available to them under the individualistic pre-insolvency debtcollection regime). Suppose that such an actual creditor $\mathrm{C}$, who is well-poised to win an individualistic race for the insolvent's assets, finds that he has been deprived of this advantage by the automatic stay. How would the CBM justify this to him? Suppose that the model is not based on what actual people would have done, and we run through its arguments with C. C's response would surely be along these lines: "So you say the imaginary participants in an imaginary agreement would have given imaginary consent to the stay. Fine, those imaginary people must be held to their imaginary choices. How precisely does that justify depriving me of my advantageous

\footnotetext{
${ }^{51}$ Thomas Jackson and Robert Scott, "On the Nature of Bankruptcy: An Essay on Bankruptcy Sharing and the Creditors' Bargain" (1989), 75 Virginia LR 155 ('Jackson and Scott, "Nature"), 160. I reproduce this quotation here to indicate the centrality of this feature of the CBM even in what Duggan describes as an "expanded" and at least in some ways "more nuanced" version of that model; see "Contractarianism", 478.

${ }^{52}$ Jackson, Bankruptcy, 59 fn. 80.

${ }^{53}$ Ibid., 15 .

${ }^{54}$ Ibid., 30.
} 
position?" To avoid C's retorting thus, the CBM must, at the very least, be able to claim that the stay would have been consented to, not by some non-existent 'archetypal' or 'representative' creditors, but by $\mathrm{C}$ himself ex ante. Only then can the model even attempt to justify coercing the non-fictional $\mathrm{C}$ into giving up his favourable position. ${ }^{55}$

In any case, it would not take matters any further to say that the CBM is based on the choices of fictional creatures of some description, perhaps of 'representative' creditors of the sort we could expect to find in various insolvency cases. Duggan attempts to defend the CBM in this sort of way, by suggesting that it might be consistent with the model's role for it to ask:

"no longer about actual creditors' likely preferences in a particular case [but rather to focus on] what the legislator [hoping to be informed by the CBM about the appropriate response to corporate insolvency] thinks creditors are likely to prefer across the range of insolvency cases." 56

This, however, veers dangerously close to missing the point. The CBM refers either to the hypothetical consent that would supposedly be given to the automatic stay by the actual creditors in an, or any given, insolvency, or it does not. If the latter, then the model's hypothetical 'consent' is shown up even at this early stage as a fake incapable of telling us anything about how "real world parties" ought to be dealt with. It is no good talking about "the range" 57 of insolvencies, unless you can analyse (let us be generous) at least a very large proportion of actual insolvencies in a way consistent with the model, unless you can point to the actual creditors in these insolvencies and employ the CBM to show why the automatic stay is, for each of them as an individual, in their interest. If this cannot be done, then it must surely be conceded that the model is unfaithful to its defining tenet, and is unable to show that the automatic stay in fact mirrors the self-interest-driven agreement that would have been struck by those actual creditors to whom it now applies.

Remember, after all, that the bargain is supposed to be a hypothetical one, and no transaction costs are involved. We must ask why the CBM still needs, as Duggan appears to be suggesting it does, to resort to the agreement of fictional creatures one might expect, in some unexplained way, to encounter in "the range" of insolvencies. If it can prove that actual creditors in an, or any given, insolvency would agree to the stay if they could bargain together without incurring transaction costs, any argument that some elusive creatures somehow 'representative' of possible future creditors in "the range" of insolvency cases would do the same is superfluous and simply pointless. But suppose the CBM must appeal to the consent of these fictional creatures must, as it were, narrow its eyes so as to omit the precise details of any given case, in an attempt to capture the broad outline of "the range" of insolvency cases - because it can not prove that

\footnotetext{
${ }^{55}$ It is clear this is what the model's progenitors are in fact trying to achieve; see e.g.. Jackson and Scott, "Nature", 160.

56 "Contractarianism", 468, defining what he calls 'Position 2'. I attempt to make sense of this rather mysterious construct below. For the time being, however, note Duggan's contrast between [A] "actual creditors' likely preferences in a particular case" and [B] "what the legislator thinks creditors are likely to prefer across the range of insolvency cases". The creditors involved in each one of "the range" of insolvency cases are of course "actual creditors in [that] particular case". On Duggan's understanding of the CBM, then, is this model based on the likely preferences of actual creditors in (at the very least) a majority of these cases? While I am not certain, the tenor of this part of Duggan's argument, including, as noted, the manner in which he contrasts $[\mathrm{A}]$ and $[\mathrm{B}]$, does suggest to me that he does not think so.

${ }^{57}$ I will stick to Duggan's words in this argument since it is difficult to be confident about how the expression "the range" of insolvency cases is to be understood: it is unclear whether it refers to all such cases, or most of them, or a sufficiently large minority of them, etc.
} 
actual creditors themselves in an actual insolvency would have agreed to the automatic stay. In that case, the model must explain how fictional creatures with all the relevant attributes of actual creditors would come to a different decision. And if these fictional creatures do not have all the relevant attributes of actual creditors, then how do their supposed decisions justify coercion against actual creditors who are different in those relevant respects? ${ }^{58}$ Again, the only answer available within the framework of the CBM is that while it concerns hypothetical choices, those choices would have been made by Real Parties in any (or all) actual transactions.

\section{Natural Ignorance, Tort Creditors and Shareholders}

Note next that the hypothetical bargain is to be concluded by Real Parties negotiating with each other in what I called 'Natural Ignorance'. In this state, the parties, while unaware of the eventual outcome of the (or, I suppose, any particular) transaction in anticipation of which they are bargaining, remain aware at all times of their own identities and attributes and of how they would be treated if there were no automatic stay. So for example:

"A central premise underlying this Creditors' Bargain conceptualization is that a system of [non-insolvency] law entitlements is already in place and that parties know [at the time that the hypothetical bargain is to be struck] what their priority positions will be so long as [non-insolvency] law continues to govern their rights." 59

Natural Ignorance allows parties to know whether they are secured or unsecured, faster at collecting debts or friendlier with the debtor or better at bargaining than other creditors. ${ }^{60}$ This knowledge shapes the process of (the notional) negotiations.

It is important to remember not only the brute fact, testified to by their text, that the progenitors of the CBM explicitly base their model on Natural Ignorance, but also that acknowledging their adherence to it is the only way in which to explain certain highly important aspects of their model.

The treatment of involuntary creditors (for example, victims of the debtor's tort with claims for compensation against it) is a particularly illuminating example. ${ }^{61}$ The CBM's progenitors have in mind an hypothetical agreement among real people who know they will lend to the company but do not know what will then happen to their debtor's business. Naturally, therefore, they think real involuntary creditors could not be invited to participate in the notional bargain, since they would not know at that time (ex ante) that they would later unexpectedly be

\footnotetext{
${ }^{58}$ The same applies mutatis mutandis to the analytic role of the CBM. If the only thing the CBM can explain is how the automatic stay serves the interests of fictional people who do not bear sufficient resemblance to real-life creditors, then it provides little help in understanding the real world.

${ }^{59}$ Jackson and Scott, "Nature", 160; this, remember, is according to Duggan the "expanded" and "more nuanced" version of the model.

${ }^{60}$ See the treatment of these points in what Duggan calls the "simple" version of the CBM, Jackson, Bankruptcy, 15, 30 and 59 fn 80, etc. "Simple" or not, Jackson's position here is perfectly - and the only one - consistent with that which he adopts in Jackson and Scott, "Nature", for example, at 160.

${ }^{61}$ It should be noted that there are unlikely to be any tort creditors in a vast majority of UK corporate insolvencies; for some of the ways in which such creditors are given protection outside of the insolvency regime, see Corporate Insolvency, 151-152. For an analysis of the injustice done to tort creditors in one particular English insolvency, see Look Chan Ho and R. J. Mokal, "Interplay of Administration, Liquidation, and CVA - Part I" (2004), 25(1) Company Lawyer 3, and R. J. Mokal, "Interplay of Administration, Liquidation, and CVA - Part II" (2004), 25(2) Company Lawyer 35.
} 
forced to extend credit. It is for this reason that the model's progenitors state that involuntary creditors "would not fairly be considered participants in a creditors' bargain." 62

I pointed out in the book that it would not help to suggest that all that the CBM's progenitors would need to change their position on this point would be for them to ask what rule would hypothetically be picked by tort claimants before they knew that the tort would be committed against them. ${ }^{63}$ The reason, I argued, was that this move would contradict Natural Ignorance, a fundamental element of the model. Without responding to this point, Duggan asserts that a few minor tweaks to the model (which I consider below) would enable it to cover tort claimants:

"it is plausible to suppose that a prospective tort victim, bargaining in advance of the law, would agree on a collective system of debt collection in the debtor's insolvency if assured of the kind of 'disaster relief' [envisaged by the CBM's progenitors].",64

Two immediate problems with Duggan's suggestion are worth noting. First, if it really was so obvious that the explanatory and justificatory ambit of the CBM could so easily be expanded so as to include tort claimants, it would seem surprising (to put it no more strongly) that the perceptive people writing in the CBM tradition failed to spot this trick. This surprise could only intensify when it is noticed that the proponents of the CBM had not simply overlooked the position of tort claimants. Instead, they explicitly considered whether the CBM could be developed so as to cover such claimants, but upon reflection and even in the "expanded" and "more nuanced" version of the model ${ }^{65}$ concluded that it would be conceptually impossible for it to do so:

"[Whatever] the merits of the claim that society owes [tort] victims protection[,] this protection does not derive from the consensual arrangements that would underlie any ex ante Creditors' Bargain. Distributions to nonconsensual claimants are conceptually different from those that would be agreed to in any bargain in which individual selfinterest was a central feature."

Secondly and in any case, however, Duggan's suggestion lacks plausibility. He says, as we saw, that tort claimants might, by being promised certain advantages, be persuaded to participate in the collective regime characterised by the automatic stay. But tort claimants cannot bargain with themselves. The idea behind the CBM is that all creditors participating in the hypothetical negotiations with each other would come to realise that it would be better for each of them to co-operate in creating the collective regime than to compete under the individualistic one. The desire to avoid having to compete provides the incentive to co-operate. ${ }^{67}$ So what about the other creditors? What advantage would they see in bargaining to a co-operative agreement with

\footnotetext{
${ }^{62}$ Jackson and Scott, "Nature", 177

${ }^{63}$ Corporate Insolvency, 39.

64 "Contractarianism", 470 n. 30 (original emphasis).

65 "Contractarianism", 478.

${ }^{66}$ Jackson and Scott, "Nature", 178 (emphasis added). Duggan quotes from the relevant part of this passage, but evidently considers that all that stuff about "conceptual difference" is overblown. On this, see further below.

${ }^{67}$ On more than one occasion, Duggan appears to overlook the point that $\mathrm{X}, \mathrm{Y}$ and $\mathrm{Z}$ reach an agreement not merely when $\mathrm{X}$ decides that he wishes to agree with $\mathrm{Y}$ and $\mathrm{Z}$ on certain terms, but only when $\mathrm{Y}$ and $\mathrm{Z}$ also decide that they too wish to agree with $\mathrm{X}$ on those same terms; along with his position on tort creditors, see also "Contractarianism", 469-470. What Duggan says there is considered below.
} 
tort claimants rather than to compete against them? As I explained in the book, ${ }^{68}$ bargaining in this context would be about giving up some pre-agreement leverage in return for other bargainers doing the same. That at the very least is involved in the give-and-take of negotiations to reach an agreement. But what would your average tort claimant, or even a group of them, have to offer to bank-, director/shareholder-, Crown-, trade- and even employee-creditors in order to tempt them into giving up some of the advantages they enjoy under the general (pre-insolvency) law?

Would these other types of claimant be worried that in an individualistic race to collect on debts against their mutual debtor, tort claimants might pip them at the post? Any suggestion to that effect would be fantastical. Under the pre-insolvency law, tort claimants in general require far more time and consume more resources in even establishing their claim than other types of creditor. They might have to prove that the debtor owed them a duty of care, for example, and that it had breached that duty. Contrast the position of most contractual claimants who would simply point to the terms of the contract, or the taxing departments of the Crown who must show merely that the debtor had traded and/or consumed goods or services, or even employees who must establish only that they had worked for a period for the debtor. Tort claimants then generally need to demonstrate that the debtor's breach of duty has resulted in harm to them, and they must provide evidence and arguments with a view to quantifying that harm. Taking this last step is particularly difficult for those who have suffered latent injuries or those who are remote in the chain of causation, etc. Note again the contrast with most other types of creditor. Non-tort creditors are for this reason hardly likely to be left quaking in their racing shoes at the thought of having to compete against tort claimants. This would be even truer of those creditors - banks, the Crown, certain commercial counterparties - who are repeat players in the market and thus relatively more used to having to collect from recalcitrant debtors than the average tort claimant.

Nor can most tort claimants gain much leverage in the hypothetical bargaining process by claiming credibly that under the individualistic regime, instead of necessarily having to litigate against the debtor, they would be able to put pressure on it to settle out of court. Disregard for a minute the fact that settlement negotiations usually operate in the shadow of the law in any case, so that the difficulties expected to be encountered in litigation by tort claimants would also for that reason be relevant to determining whether they would be able to compel the debtor to settle. Consider again the difference between the leverage available to tort and to other claimants. The average debtor might wish to keep its bank happy out of fear that the latter would otherwise starve it of funds or call in its loans or seize collateral; might wish to keep particular trade creditors onside in case they withdrew custom or favourable terms; might wish to retain the services of at least some key employees in order to continue trading; and perhaps, might even fear that non-payment of taxing authorities might provoke them to shut it down using the sorts of administrative or quasi-judicial powers available to such authorities in some jurisdictions. But it is difficult to imagine from what source the average tort claimant might gain some similar leverage over the debtor. In general, the debtor simply does not need the co-operation of this category of claimant. What is more, whereas a solvent company might be concerned about the reputational damage that might result from leaving (particularly a large group of) tort claimants unpaid, a distressed company could be expected to attach much greater relative weight to the immediate and more certain harms of the sort described previously in this paragraph than the more remote and more speculative harm to its reputation.

The point is simply this. The CBM explains the nature of the collective regime by claiming that all the relevant creditors would agree to abstain from racing against each other because they would regard this to be in their self-interest. However, no plausible reasons are

${ }^{68}$ Corporate Insolvency, 53-54. 
available to suggest that non-tort claimants would find it in their interest to allow tort claimants to take the benefit of participation in an agreement in which non-tort claimants gave up their respective pre-insolvency enforcement advantages. Since non-tort claimants have no reason to fear having to compete with tort claimants under the individualistic system, they correspondingly have no incentive to co-operate with them so as to create a collective one. ${ }^{69}$

That the CBM simply cannot accommodate the position of tort claimants ${ }^{70}$ is not some unfriendly accusation that I have levelled at the CBM. The progenitors of that model themselves considered the issue in some detail while propounding the "expanded" and "more nuanced" version of the model. They came to the explicit conclusion, as noted, that any protection afforded by insolvency law to tort creditors was not conceptually consistent with the model's prescriptions, given the model's "central" dependence on the self-interest of creditors in manufacturing the hypothetical agreement. ${ }^{71}$ And while there is much on which I differ from them, there is no doubt in my mind that they were right on this point, for the sorts of reasons I have just explained.

In the course of a sentence in one of his footnotes, however, Duggan overrules us all. ${ }^{72} \mathrm{~A}$ more detailed account of his reasons for doing so would have been illuminating. ${ }^{73}$

Note, finally, that in assessing the success or otherwise of the CBM, whether the interests of shareholders can be accommodated within this model is, in and of itself, of no great probative interest to me. Duggan may think otherwise. ${ }^{74}$ I concede that a fragment of one sentence of my text on the page cited by Duggan is unqualified ("shareholders are not included in Jackson's model"). Duggan's reading of that fragment shows that it ought not to have been so unqualified. Be that as it may, I am not, and have never been, committed to the view that the CBM cannot be propounded so as to include shareholders. Note, first, that immediately prior to the sentence in question, I cited ${ }^{75}$ that part of the work of the CBM's progenitors which expands the model to include shareholders. ${ }^{76}$ This should indicate, I hope, that I am not committed to any unqualified proposition that the CBM could not be modified so as to accommodate shareholders in some appropriate capacity. Secondly and in further support of this point: in a paper published in 2000, when I was still sympathetic to the CBM tradition, I myself explicitly expanded the "Creditors"' Bargain so as to include shareholders within its ambit! $!^{77}$ Admittedly, this might not be readily apparent to someone who had read the book but not that previous paper. ${ }^{78}$ Finally and most

\footnotetext{
69 Alternatively, even if agreement were to be reached, it would be one reflecting the pre-agreement advantages and disadvantages of the various parties, not one pursuant to which non-tort claimants would give up their superior position vis-à-vis tort claimants for the privilege simply of being treated on par with them. This point is considered below.

${ }^{70}$ Alternatively, that tort creditors ought to enjoy an inferior position within the insolvency system, given their comparatively weaker position in the hypothetical bargain as against other types of claimant.

${ }^{71}$ See again Jackson and Scott, "Nature", 177.

72 "Contractarianism", 470, footnote 30.

73 The reason he does provide - his invocation of what he calls Position 2 - is examined in the following sub-section.

74 “Contractarianism”, 464, including footnote 10, citing Corporate Insolvency, 69.

${ }^{75}$ Corporate Insolvency, 69, footnote 36.

76 Jackson and Scott, "Nature", 194-196.

77 See Mokal, "An Agency Cost Analysis of the Wrongful Trading Provisions: Redistribution, Perverse Incentives and the Creditors' Bargain" (2000) 59(2) Cambridge LJ 335 ('Mokal, "Wrongful Trading”), 345-346.

78 That said, see, however, Corporate Insolvency, 276-279, particularly text to footnote 71, and footnote 72 . On these pages, citing my 2000 paper, I sketched out (and then rejected) the argument that in a real-life $e x$
} 
importantly, however, the substance of the discussion of which the fragment in question forms part could, on a good day, have spoken for itself. The sentiment in this part of my discussion was that the ACM "rejects the narrow concerns of the CBM, which restricts participation in the ex ante agreement to those who have contracted for legal rights to the debtor's assets once insolvency has occurred". ${ }^{79}$ Shareholders, qua shareholders, do not fall into this category. This remains true of every version of the model that has been explicated by the progenitors of the CBM. Even when, as in the work I mentioned at the top of this paragraph, shareholders have been let into the model, this has been in their capacity as contributors of post-distress "new value" to the debtor, and not merely qua its original shareholders. And the remainder of the sentence on whose fragment Duggan apparently relies refers in this context to tort creditors, who are, as I noted there, not given entry into the model.

To reiterate: I claimed in the book $^{80}$ that the ACM does, in a manner that the CBM cannot, provide a voice to each of those parties (including, as and if appropriate, the debtor itself, its shareholders, managers, all creditors voluntary or not, and anyone else at all) who is affected by peculiar insolvency issues. I still adhere to that view.

\section{E. The Incoherence of the Ex Ante Position}

Does the CBM's ex ante position specify a unique, morally privileged point, which is determinate rather than forever shifting in line with each party's assessment of their self-interest, and which is such that even preferences driven merely by self-interest ought to be considered binding if ascertained as at that point?

I have argued that the answer to both questions must be a clear no. On no interpretation of the ex ante position does it constitute a unique or morally privileged point in time, and any consent counterfactually given by Real Parties in Natural Ignorance cannot be considered binding. Consider an analogy based on the same premises:

Suppose I did not know the value of my painting on Monday; if you had offered me $\$ 100$ for it then, I would have accepted. On Tuesday I discovered it was valuable. You cannot argue that it would be fair for the courts to make me sell it to you for $\$ 100$ on Wednesday. It may be my good fortune that you did not ask me on Monday; but that does not justify coercion against me later. ${ }^{81}$

For those tempted to respond that this analogy is unfair to the CBM since it turns on a mistake, here is a variant: If you had asked me on Monday, I would have sold my share portfolio to you for its then $\$ 100$ market value. You did not, and the market value of the shares jumped to $\$ 10,000$ on Tuesday. It should be obvious that my counterfactual consent on Monday would not justify forcing me on Wednesday to hand the portfolio over to you for $\$ 100$, on the basis that I would have been willing to, though I did not in fact, sell it to you for that price. Counterfactual consent given by Real Parties in Natural Ignorance justifies nothing.

ante bargain, creditors, shareholders and managers would all agree to tie the managers' loyalty to the creditors' interests, should the debtor company become irredeemably distressed.

${ }^{79}$ Corporate Insolvency, 69.

${ }^{80}$ Compare Duggan's point (2) in "Contractarianism", 464.

${ }^{81}$ R. Dworkin, "The original position", in N. Daniels (ed.), Reading Rawls: Critical Studies on Rawls' 'A Theory of Justice' (Stanford Univ. Press: Stanford, 1989), 16, 19. 
Or consider the automatic stay itself. Here is Scenario 1. C Ltd. is in a line of business which requires the extension of credit. Of the first ten loans $\mathrm{C}$ ever makes, five have to be collected through court proceedings. Three of these debtors go into insolvent liquidation. $\mathrm{C}$ is young, its employees are still learning to work together, and its finance director is inexperienced in ordinary (non-insolvency) debt-collection procedures. If asked before extending credit whether the automatic stay on unsecured claims was in its self-interest, $\mathrm{C}$ would have replied in the affirmative all five times. Of its next ten loans, there are again court proceedings against five debtors and three of these again end up in insolvent liquidation. C's employees are now proficient and well-coordinated, and its finance director can count on them to ensure claims will be filed, and judgments obtained and executed, speedily. If now asked before making each of the bad loans, $\mathrm{C}$ would calculate that the automatic stay was in fact not in its self-interest, since it could do far better under the individualistic non-insolvency regime. Now the Real Parties premise requires "actual people, deploying actual endowments of skill" to make the calculation of selfinterest. So we must ask $\mathrm{C}$ whether it finds the stay acceptable. But what is the correct ex ante position from which this calculation is to be made by $\mathrm{C}$ ? Is it at the very beginning, when $\mathrm{C}$ has just started in the business of lending? Or after its tenth loan, or its tenth bad loan? It matters immensely when the calculation is made, but the ex ante position as defined by Natural Ignorance provides no answers. ${ }^{82}$

But if we can not decide when to ascertain creditors' self-interest, we can not decide whether they would consent (counterfactually) to the automatic stay. Remove counterfactual consent, and nothing is left. The whole edifice comes tumbling down. The CBM justifies nothing.

But perhaps the argument sketched out above misunderstands the notion of the ex ante position? Perhaps the focus should not be on one creditor over a series of transactions, but rather on all the creditors in a (or any) transaction. Judged ex ante, then, before any loans are made, would it be in the self-interest of each relevant creditor to accept the stay on unsecured claims?

This version of the notion of the ex ante position actually makes things a bit worse. Here is Scenario 2. Let us take C Ltd. as it is after having made twenty loans and having dealt with the consequences, a consummate collector of debts, lining up to extend credit for the twenty-first time. Let us also consider E, F and G, highly-skilled computer engineers who work for the debtor-to-be at a time when there are plenty of such engineers in the job market, and who have never worked for an employer which became insolvent. They of course will become creditors for back pay and accrued holiday remuneration, etc. Before any lending takes place, C's finance director meets with E, F and G to make a binding choice as to what should happen, should their debtor become insolvent. It is suggested here that no agreement can take place. The Natural Ignorance premise allows parties to be aware of their own attributes, to know one of them is "systematically faster" than others. Under these conditions, C would insist on a free-for-all system, while E, F and G, knowing they can never compete, would hold out for the stay on all claims.

This game can be played any number of times, with different parties making decisions on the basis of their own ability to collect debt, and on their assessment of their particular competitors' abilities in each transaction. Since the parties know they differ in their debtcollection skills and their ability to influence the debtor, no agreement would be reached. For well-resourced repeat-playing creditors, for whom the net expected returns from competing under the individualistic regime are overwhelmingly likely to be higher than the net expected returns from cooperating under a collective one, there is no rationally self-interested reason for

${ }^{82}$ Dworkin, "Efficiency", 580-1, considers a similar argument in the context of tort law. 
participation in the latter. In respect of any given transaction, the same holds for creditors with a connection with or influence over the debtor's management. ${ }^{83}$ What is more, parties are merely expressing preferences based on self-interest, and nothing in the CBM leads us to believe they should not be allowed to alter their preferences from transaction to transaction. Not only will agreement between unequal creditors not be reached in a particular transaction, then, it will never be reached in the ex ante position to any transaction. ${ }^{84}$

Once again, this conclusion is hardly specific to those unfriendly to the CBM. Jackson himself virtually concedes that a collective insolvency regime would only emerge from the hypothetical bargain on the back of the false assumption that all of the "real-world" creditors are "homogenous" in their debt collection and bargaining skills and that none has particular influence with the debtor. ${ }^{85}$ Realising that this conclusion would render his model entirely hollow, Jackson does then attempt to paddle away from it, providing what I reckon are three reasons for suggesting that even for non-homogenous creditors, the individualistic regime would be undesirable. First, he claims, continuation of the individualistic system would necessitate the incurring of monitoring costs, and secondly, it would leave some residual uncertainty about the creditors' recoveries in particular transactions.

These attempts to salvage something for the CBM are obviously feeble ${ }^{86}$ It simply is not true that monitoring costs would impact equally upon repeat players (for example, institutional lenders, some trade and even Crown creditors), who would enjoy economies of scale and accumulated expertise in undertaking such monitoring, as they would upon one-off lenders (for example, employee creditors, consumer pre-payers, some trade creditors, any tort claimants), who would not have these advantages. And repeat players can deal with uncertainty by diversifying, thereby (more than) making good what they lose in some races by winning others. This is something one-off lenders cannot do. Again, Jackson concedes that "diversification is a response to risk-aversion"; but he then attempts to qualify the concession by adding that "individualistic remedies lead...to a collectively undesirable race". ${ }^{87}$ This qualification is no more persuasive then Jackson's original argument. Within the CBM, well-diversified repeat players do not care about what is "collectively undesirable"! They are motivated, let us recall, solely by their own selfinterest, and so appeals to the collective weal should not be regarded as holding any sway with them. Nor would they be moved by the fact that the switch-over to a collective system is likely to preserve the most value in the debtor's estate. Self-interested repeat players would prefer a larger slice of a smaller pie to a smaller slice of a larger pie. And while the collective regime would usually lead to a larger pie, winning an individualistic race might lead to a larger slice.

It should be manifest, then, that repeat players simply do not need the comforts of the automatic stay in anything like the way that one-off transactors do. The same holds for creditors with influence over the debtor, for example, those connected with its managers or controlling shareholders. It remains a mystery within the CBM construct, therefore, why repeat players, wellresourced creditors and those connected with the debtor would agree to the cancellation of their

\footnotetext{
${ }^{83}$ Contra Duggan, "Contractarianism", 468; on this, see further below.

${ }^{84}$ Or alternatively, any collective regime emerging from such an agreement would look very different from the one we in fact have; see the discussion of the treatment of vulnerable claimants, below.

${ }^{85}$ Jackson, "Entitlements", 863-864; Jackson, Logic, 15.

${ }^{86}$ As I pointed out in Corporate Insolvency, 57-59. At "Contractarianism", 469, footnote 28, (see also ibid., 468), Duggan provides a reference to these responses but does not address them, apparently on the basis that an amendment to the CBM by incorporating what he calls Position 2 would allow the model to sidestep most of my objections. I discuss Position 2 below.

${ }^{87}$ Jackson, "Entitlements", 863.
} 
advantages under the individualistic regime, for the privilege of ranking on par in a collective forum with those they would otherwise be highly likely to beat.

I said that Jackson comes up with three arguments in support of his suggestion that the CBM's hypothetical bargain might lead to the automatic stay even if it were to drop the false assumption that all creditors in the real world are homogenous. Well, his third reason is as follows. He asserts that "there would be distinct advantages to a legal rule that presumed equality in the position of all creditors with similar legal entitlements, instead of delving into a case-bycase examination of factors such as 'knowledge' [of] or 'friendliness' [with the debtor]." 88 Apparently, this is on the basis that it would be sensible for "a legal decision maker" to create rules only roughly based on the particular attributes of various types of creditor, instead of trying to accommodate the immense possible diversity of all the creditors in all the insolvency proceedings a legal regime would be expected to regulate. On this basis, the automatic stay would be a good practical response to the problems anticipated under the individualistic system. ${ }^{89}$ There are several problems with this argument, of which I will mention two. Firstly, the switch to the perspective of the "legal decision maker" indicates that we are beyond the realm of the CBM, which of course is meant to focus on what creditors would prefer. ${ }^{90}$ And secondly and as a result, the model here becomes entirely question-begging. Recall that the CBM is supposed to tell "legal decision makers" what insolvency laws to enact by showing what creditors would prefer and hence consent to. And it determines what creditors would prefer by asking what rules would be in their respective self-interest. So unless it can say what would be in the self-interest of various creditors, it can tell us nothing about what the content of insolvency law ought to be. Here, as we have seen, the CBM cannot show why all creditors equally would find the collective regime marked by the automatic stay to be in their respective interests. Some would, but others would not. So even if Jackson is right that insolvency law should eschew enquiries into the circumstances of particular creditors in particular insolvencies in order to impose just one rule on all, he signally fails to show what that rule ought to be, or in other words, why it should be the automatic stay rather than the free-for-all!

It follows, therefore, that the CBM can neither explain nor justify the automatic stay.

\section{F. The Nature of Bargaining and Duggan's Defence of the Creditors' Bargain Model}

So what does Duggan have to say about all this? ${ }^{91}$ His position is intriguing. While agreeing with me that it is important to settle upon the correct interpretation of the CBM's ex ante position, ${ }^{92}$ he thinks that he has an answer. The ex ante position might, he says, be interpreted in one of two ways:

"(1) in advance of any creditor lending to a particular debtor (Position 1), or (2) in advance of the enactment of the insolvency laws (Position 2)." 93

\footnotetext{
${ }^{88}$ Bankruptcy, 15 fn. 18.

${ }^{89}$ Ibid., 30-1, including fn. 18.

${ }^{90}$ At "Contractarianism", 468, Duggan reproduces this argument, but appears to have missed its import, which is explained in the remainder of this paragraph, and which derives from Corporate Insolvency, 59. As noted, he appeals to what he calls Position 2 to suggest that the CBM could side-step this argument. Can it? We will soon see.

${ }^{91}$ Several of his arguments have of course been discussed above.

92 "Contractarianism", 467, 470 and 480.

${ }^{93}$ Ibid., 467.
} 
Having apparently found significant textual support in the CBM scholarship for both Positions, Duggan claims that the model's progenitors "vacillate[] between Positions 1 and 2, apparently without noticing the inconsistency." ${ }^{94}$ He holds that while several of the arguments I level against the CBM (some of them discussed above) are effective if the model's ex ante position is interpreted as in Position $1,{ }^{95}$ the model might well be rescued if only it would adopt Position $2 .{ }^{96}$

I found that making sense of the distinction between Duggan's two Positions calls for heroic effort. There would appear to be only one sensible way of understanding the distinction. While he does contrast the two Positions - indeed, while he suggests that there is an "inconsistency" between them - Duggan should not, it seems to me, be taken to be suggesting that Position 1 refers to a state of affairs which is not "in advance of the enactment of the insolvency laws". Consider the alternative: Since the two Positions are supposed to be different, could it be sensible to understand Position 1 as the state of affairs in which the insolvency laws had already been enacted by the time the CBM operated to ascertain the terms of the hypothetical bargain? Besides being flatly contradicted by the writings of the CBM's progenitors, ${ }^{97}$ that suggestion would be absurd: What would the parties be supposed to be bargaining about in that case, since, presumably, the collective regime would then already exist? ${ }^{98}$ It is surely a sine qua non of any interpretation of the hypothetical bargain that it takes place in a state of affairs where insolvency law is assumed to be absent. And in fact, as I have noted, it is clear beyond any doubt - including from the two passages Duggan cites as exemplifying Jackson's commitment to Position 1 - that the hypothetical bargain is to be struck in advance of the enactment of a "collective liquidation system". ${ }^{99}$ The only coherent way of understanding Position 1 , then, is to take it as referring to a state of affairs where no lending has yet taken place, and where no insolvency laws have yet been enacted.

This then suggests the only coherent understanding of Duggan's Position 2, though, as before, we really have to rely heavily on the principle of sympathy. Since Position 2 is supposed to be different from and "inconsistent" with Position 1, that could only be because Position 2 refers to a state of affairs where some relevant creditor has already made a loan to some relevant debtor. Of course this too is clearly contradicted by the CBM's progenitors, who repeatedly insist that the creditors are supposed to engage in the hypothetical bargaining "before extending credit". ${ }^{100}$ But in order to make any sense of what Duggan might have in mind, we have to go along with him and ignore this part of what the CBM's authors say. At least, doing so does not

\footnotetext{
${ }^{94} \mathrm{Ibid}$., 468, apparently attributing this point to Corporate Insolvency, 58. For the reasons to be explained in the text here, I am not sure I deserve or would wish to accept this credit.

95 "Contractarianism", 467, 470, and 480.

96 "Contractarianism", 468, 469, and 470.

${ }^{97}$ See for example Jackson, Logic, 15, and Jackson and Scott, "Nature", 160.

${ }^{98}$ In the CBM, it is the creditors' desire to avoid having to compete under the individualistic system that supposedly creates the incentive for them to co-operate to create the collective one. If the alternative to the hypothetical bargain were still the collective regime, this structure of reasoning would be rendered nonsensical.

${ }^{99}$ Ibid., 467, citing Jackson, "Entitlements", 861. The same holds for the other example Duggan provides of Position 1, at "Contractarianism", 470 at footnote 30, citing Jackson and Scott, "Nature", 177. Here, too, the CBM imagines what would be agreed to in a situation where the collective insolvency regime was not in place; see for example the quotation provided above from Jackson and Scott, "Nature", 160 (emphasis added): the parties engaged in the hypothetical bargaining are at that time governed by the general law, and thus are aware of "what their priority positions will be so long as [non-insolvency] law continues to govern their rights".

${ }^{100}$ See for example Jackson, Logic, 17 at footnote 22; see also 30: "[Imagine] that we met with each other and with the debtor before making the loans".
} 
lead to absurdity in the way that doing the same with Position 1 would. In other words, then, the two Positions mark two points on the temporal continuum relating to the prospective (Position 1) and then actual (Position 2) making of a loan by a relevant creditor to a relevant debtor. Even on this understanding, Position 2 is still, I suppose, an interpretation of the 'ex ante' position, since it relates to a period before the creditors must have resort to the insolvency regime (and of course, before any such regime has been enacted). ${ }^{101}$

It is one thing to make sense of the difference between the two Positions, and quite another to understand why Duggan places such great weight on it. Given the only sensible explication of the Positions I can find, it should be obvious why the CBM's progenitors (ignoring the fact that, at least implicitly, they reject Position 2) might appear to "vacillate" between them: There is no analytically significant difference between the two Positions! What matters to the CBM is that the hypothetical bargain be struck in a state in which no insolvency laws exist, and that in this state, Real Parties in Natural Ignorance are consulted as to how they wish to be treated in their debtor's insolvency. But then the two Scenarios I have sketched out above demonstrate that such hypothetical bargaining would not produce the automatic stay. What is more, the analysis of both Scenarios, particularly of 1, clearly covers every variant of Positions 1 and 2, holding equally for the incentives of different types of creditor before and after a loan might be made. Indeed, since Position 2 involves the parties knowing more about themselves and each other than Position 1, it is less conducive to the CBM, since it is less likely to allow any agreement to be reached as between creditors aware of their relative positions in any individualistic race. ${ }^{102}$

Further, Duggan displays once again at this point an apparent misunderstanding about the nature of bargaining to which I have already drawn attention. The CBM can, he insists, predict the automatic stay by employing Position 2:

"assume three creditors: $\mathrm{C} 1, \mathrm{C} 2$ and $\mathrm{C} 2 . \mathrm{C} 1$ and $\mathrm{C} 2$ are both strong creditors (banks, nonbank lending institutions or the like) whereas C3 is a weak creditor (an employee, for example, or a weak trade creditor, or a pre-paying consumer)...The alternative version of the CBM [that is, one based on Duggan's Position 2] predicts that C1, C2 and C3 would all agree ex ante on a collective system. A collective system is in $\mathrm{C} 1$ and $\mathrm{C} 2$ 's interests given that neither of them knows the outcome of future individualistic races between them and it is in C3's interests because C3 will do better against C1 and C2 in a collective system than it would in an individualistic race."103

The attentive reader would not be surprised by what follows. First, in what way is this an "alternative" version of the CBM, when (as noted above) all writing on that model explicitly states and quite clearly enshrines the premise that the hypothetical bargain is to be, and must be, concluded "in advance of the enactment of the insolvency laws"? Given Duggan's concession that the 'standard' version of the CBM cannot predict the collective regime marked by the

${ }^{101}$ Do note, however, that all of what follows is consistent with reading Position 2 as relating to a state of affairs before any lending has taken place. The only difference resulting from understanding Position 2 in that way would be that Duggan's attempted distinction between the two Positions would then have collapsed irremediably: both Positions would then refer to a state persisting prior to the enactment of the insolvency laws and prior to the making of any loans.

${ }^{102}$ Duggan appears to concede that the more that creditors knew about themselves and each other in the context of a particular transaction, the less likely they would be all to agree to the automatic stay; "Contractarianism", 468-469.

103 "Contractarianism", 469-470, also providing a footnote at the end of this passage containing his treatment of tort claimants, which has already been discussed above. 
automatic stay, and given that his "alternative" version is absolutely identical, Duggan would appear to be in a bit of a pickle.

Secondly, assume that Duggan is right that $\mathrm{C} 1$ and $\mathrm{C} 2$ have reason to bargain with each other, and assume also that $\mathrm{C} 3$ would be better off within than outside of the collective regime and thus would wish to bargain with $\mathrm{C} 1$ and $\mathrm{C} 2$. But it must be remembered that, here, it takes three to tango: Duggan overlooks the need to explain why $C 1$ and $C 2$ would wish to bargain with $C 3$ ! There is, quite simply, nothing they would gain by sharing with $\mathrm{C} 3$ the benefits of their abstinence from racing as against each other. After all, C3 is hardly likely - "tomorrow" any more than "today"104 - to transform from a struggling one-off transactor ${ }^{105}$ or inexperienced and poorly resourced player lacking in bargaining power ${ }^{106}$ into a bank-beating debt collector! Since $\mathrm{C} 1$ and $\mathrm{C} 2$ do not have any reason to fear competing against $\mathrm{C} 3$, then, they have no reason to wish to co-operate with it either. So $\mathrm{C} 3$ is out, as is any suggestion of a collective regime marked by an automatic stay equally applicable to all. Instead, in an hypothetical bargain as between themselves, it would be in the respective self-interest of both $\mathrm{C} 1$ and $\mathrm{C} 2$ simply to agree not to race against each other, thus controlling duplicative monitoring costs inter se, mitigating any risk aversion, and if necessary to further their interests and their interests alone, preserve any going concern surplus. They could do this in any of several ways. Here is one with empirical support in the real world: Whichever of $\mathrm{C} 1$ and $\mathrm{C} 2$ lends first would monitor on behalf of them both. Assume that this is $\mathrm{C} 1$. When $\mathrm{C} 2$ lends later, it would compel the debtor to authorise $\mathrm{C} 1$ to release the results of its monitoring to $\mathrm{C} 2$. $\mathrm{C} 1$ would be rewarded for this monitoring either by priority over $\mathrm{C} 2$ or with a higher interest rate or perhaps both. ${ }^{107}$ When the debtor becomes insolvent, $\mathrm{C} 1$ and $\mathrm{C} 2$ would race (against other creditors, though not inter se) to collect on their debts to the maximal degree, leaving $\mathrm{C} 3$ spluttering at the starting line.

Thirdly and even ignoring these points, are $\mathrm{C} 1, \mathrm{C} 2$ and $\mathrm{C} 3$ real creditors of exactly the sort one would find in an actual, real-life insolvency, or are they rough approximations of the sort of creditor one might expect to find in "the range" of insolvency cases? ${ }^{108}$ If the latter, then how can their consent tell us anything about how the law ought to treat real creditors? How can consent given by a rough approximation of me justify coercion against me? Fourth and finally, even if $\mathrm{C} 1, \mathrm{C} 2$ and $\mathrm{C} 3$ are the sorts of creditors one would find in a particular real-life insolvency, they have not in fact consented to the automatic stay. So how can consent that they might have given but did not in fact give be held binding against them, any more than the consent I would have given but did not give to the sale of my share portfolio when it was worth $\$ 100$ justify depriving me of that portfolio for that amount even though it is now worth many times as much?

${ }^{104}$ Compare the last two sentences at "Contractarianism", 468. It would require a strong belief in a miraculous afterlife to think that "today's" vulnerable employee-creditor C3 could somehow be reincarnated as "tomorrow's early bird", able to outrun bank-creditors $\mathrm{C} 1$ and $\mathrm{C} 2$ in individualistic races to collect. In any case, most institutional lenders in the position of $\mathrm{C} 1$ and $\mathrm{C} 2$ are unlikely to have any reason to believe in such miracles, and thus for being induced into a self-denying ex ante bargain with $\mathrm{C} 3$.

${ }^{105}$ Most employees do not have to attempt to collect from insolvent employees too many times in their working lives, and a consumer pre-payer would have to be particularly unlucky to find itself in an analogous position.

${ }^{106}$ Weak trade creditors, for example.

107 Consider the facts of Re New Bullas Trading Ltd [1994] 1 BCLC 485, discussed in Corporate Insolvency, 204-205. Under English law, secured creditors are immune from having to participate in the collective liquidation regime, and so may continue to pursue individualistic enforcement strategies despite the initiation of liquidation. The behaviour of secured creditors thus provides some evidence of how creditors (particularly institutional ones, who are the most frequent holders of security) would act in the absence of a collective regime.

${ }^{108}$ See again "Contractarianism", 468. 
And finally and for completeness, how could consent that might have been given by a rough approximation of me but in fact was not, possibly be held binding upon me?!

While the reader would of course make up her own mind, it seems to me that Duggan has provided no response to any of these questions. His attempt to defend what he thinks is a new version of the CBM must therefore be considered less than a success.

\section{G. The Creditors' Bargain and the Authentic Consent Model}

I noted in the book that the stay on individual actions by unsecured creditors has been a part of bankruptcy and insolvency law, as it were, from the day that there has been such a law. The collective regime defined by the stay is the most central and unchallenged aspect of the process of winding up companies. The stay on (in the UK) unsecured claims is a "provisional fixed point", then. That it should exist and be part of insolvency law is one of our "settled convictions" about this area of the law. ${ }^{109}$ We feel confident, and can agree, that independent action by the unsecured creditors of an insolvent person should be stayed, whether or not we agree on any other aspect of the insolvency regime. Very persuasive reasons indeed would have to be produced to convince us that the stay should no longer be part of insolvency law. Till such reasons are forthcoming, any explanatory theory of the insolvency regime should be able to account for the stay. If it does not, it can not claim to be an account of this regime.

Well, for the reasons we have just considered, we must condemn the CBM precisely because it fails this test. The model's predictions are either indeterminate, or more likely, it predicts that there would be no automatic stay, creditors who enjoy systematic advantages under the pre-insolvency regime being loath to give these up for the privilege of participating in the collective system on par with weaker competitors. ${ }^{110}$

This has very consequential implications, which appear to have been missed by Duggan. Since the CBM cannot predict, explain or justify the automatic stay - this defining aspect of the collective insolvency system - it can explain no other feature which relies upon the collectivity of insolvency law (for example, the pari passu principle ${ }^{111}$ ), or which protects or bolsters the efficacy of that collectivity (for example, the wrongful trading provisions ${ }^{112}$ or insolvency law's rules for the adjustment of antecedent transactions ${ }^{113}$ ).

What is more, since I reached this conclusion at the end of the second chapter of my book, it seems rather surprising for Duggan to have been left with the impression, a further seven chapters and 280 pager later, that the book's "main argument" is that "the ACM is different from, and superior to, the CBM as a tool for positive and normative analysis of insolvency law." "This is made doubly surprising in view of Duggan's complaint that I do "not systematically compare the two models at the level of application," that I do not "always explain how the law would be

\footnotetext{
${ }^{109}$ Drawing on John Rawls, Political Liberalism, 8.

${ }^{110}$ A third possibility, a collective regime whose distributive rules reflect the pre-insolvency advantages and disadvantages of various creditors, is considered below.

${ }^{111}$ Contra "Contractarianism", 473-475, further considered below.

112 Contra "Contractarianism", 477-479, further considered below.

113 See Corporate Insolvency, chapter 9, particularly 330-332.

114 "Contractarianism", 479-480. I suppose Duggan is right to the extent that, at least implicitly, I am claiming that the ACM can, when the CBM cannot, explain and justify the fundamental features of insolvency law.
} 
different if the CBM was used instead". ${ }^{115}$ Should the fact that I do not systematically compare the two models not count as evidence that my "main argument" was not the one Duggan attributes to me? What is more, I thought that by the end of the second chapter of my book, I had explained exactly how the law would look if dictated by the CBM: Most likely, there would be no collective insolvency regime at all! It follows also that since I could not, for the reasons above, understand how the CBM, applied faithfully and in view of its central premises, could possibly lead to the imposition of the collective regime (at least of the sort we have) in the first place, it seemed to me both difficult and pointless to engage in the distortive logical gymnastics I considered would be required to attempt to "apply" that model to particular features of the collective regime. So I engaged in this process only when that was necessary in order to address arguments extant in the literature which draw on the CBM, as about the wrongful trading provisions.

And finally, Duggan's repeated assertions that I surreptitiously "elide" the CBM with the ACM, or that the two models "converge" at the "level of application", 116 could only be accepted if it could be demonstrated that, as a first step, the CBM can predict and explain the collective regime marked by the automatic stay. Unless that could be done - and I have outlined here the main reasons for thinking that even if this could be done, it has not yet been - the CBM could obviously not "converge" at any level with the ACM, which does, or so I have claimed, explain the collective regime and the panoply of legal practices that support it.

\section{THE AUTHENTIC CONSENT MODEL AND THE AUTOMATIC STAY}

The background to the ACM is the recognition of the CBM's failure, and an appreciation of the basic reasons for that failure. In attempting to understand and/or justify legal institutions:

"one cannot merely invoke the fact that under circumstances $\mathrm{C}$ agent $\mathrm{A}$ would prefer option O. One must explain the propriety of describing the circumstances in a particular way, of attributing particular characteristics and interests to the agents in the choice position, and of giving them a particular menu of options. Perhaps this would take legal writers too far into the muddles of moral philosophy. If so, it might be the better part of valor to eschew appeal to arguments of this kind."117

All that is true, and the warning is apt. But a principled analysis and justification of insolvency law must still by sought.

\section{A. The basics of the Authentic Consent Model}

So the ACM sets off to avoid the faults of the CBM. ${ }^{118}$ Most importantly, the ACM is a contractualist theory whereas the CBM is a contractarian one. ${ }^{119}$ The ACM therefore designs its 'choice position', in which the relevant parties are to be consulted on the selection of principles to

\footnotetext{
${ }^{115}$ Both quotations are from "Contractarianism", 465 (original emphasis); see also 476.

${ }^{116}$ See for example "Contractarianism", 466, 469, 470, 471-472, 473 at footnote 45, and 474-475.

${ }^{117}$ Brudney, "Consent", p 262 (footnote omitted).

${ }^{118}$ This section presents a radically simplified version of the arguments and detailed citations to be found in Corporate Insolvency, 4-10 and chapter 3.

${ }^{119}$ Put differently, the ACM is a 'justice as reciprocity' rather than a 'justice as mutual advantage' theory. As an instance of the latter, the CBM traces its roots in the work of the likes of Hobbes, Gauthier and Posner, whereas the ACM's antecedents are in the work of Kant, Rawls and Dworkin, among others. See further Corporate Insolvency, 87-90, including footnotes.
} 
govern them in the debtor's distress, by reference to Dramatic Ignorance. This is based on the premise that the choice of principles should not be influenced by morally irrelevant features and considerations of the parties, ${ }^{120}$ for example, their gender, race, wealth, negotiating abilities, bargaining power, influence over any other party, status as a particular type of creditor, position in any/most/all individualistic races, etc. The ACM defends the characteristics it attributes to the parties whose interests are to be governed by insolvency law by claiming that the legal and political culture of society demands that when consulted on the design of institutions meant to govern them, citizens be considered free (that is, capable of forming and revising a conception of their own good), reasonable (that is, capable of being moved by considerations of fair reciprocity, or in other words, of proposing and abiding by principles of fair co-operation on the assurance that others would likewise do so), and thus equal. As equals, all relevant parties are entitled to equal consideration of their interests in the design and implementation of insolvency law.

The ACM also stipulates that the parties should go about choosing such principles while acting consistently with means/ends rationality. Note that rationality implies adherence to the dictates of transaction cost efficiency: other things being equal, it is irrational to adopt a course of action which consumes more resources than one which leaves more resources for the pursuit of other valued goals. ${ }^{121}$ And in the choice position, the parties are assumed to be motivated by selfinterest. This means they seek rights of access to or influence over their distressed debtor's assets.

Finally, the ACM decides on the menu of options to present to the parties in the choice position by asking, "What makes insolvency law special?" Insolvency law must deal only with peculiar insolvency issues. At the same time, it must give a voice to all those affected by such issues.

\section{B. Reciprocity and Self-interest}

Duggan is perturbed that the ACM does not have any resources for "weighting self-interest against reciprocity", nor for determining "the policy outcome of any given weighting". ${ }^{122} \mathrm{He}$ therefore questions whether the ACM could predict or explain the structure of the automatic stay, unless it were surreptitiously to "blur the distinction between self-interest and reciprocity." " $\mathrm{He}$ thinks that despite claiming to have drawn on Rawls's work in setting up the ACM's choice position, I have missed the point that:

"Rawls does not suggest that parties in the original position are motivated by reciprocity. They are motivated by self-interest. Reciprocity is simply a function of the limited information available to the parties in the original position." 124

\footnotetext{
${ }^{120}$ In that such features do not entitle their possessor to any greater consideration of their interests than the interests of those who do not possess them.

${ }^{121}$ Again, I hope this provides some clarification as to the relationship between equity and efficiency, which is obviously of some concern to Duggan, particularly at "Contractarianism", 466. See further below.

122 "Contractarianism", 470.

123 "Contractarianism", 471.

${ }^{124}$ Ibid., footnote 36, attributing this point to Sophia Moreau, who provided him with comments on a draft of his review. The other, related, point Duggan attributes to Moreau, at "Contractarianism", 466, footnote 14 , is that Rawls's original position is concerned with testing whether the broad principles of the constitutional structure are consistent with the demands of equality, and that, for Rawls, "It is not necessary to try to justify each rule on equality grounds." In response: (1) I explicitly introduced, and took on board the implications of, precisely the distinction to which Moreau points: "It is one thing to say that consent can be invoked to justify an institution, rule, or policy, and quite another to claim that consent directly provides a justification for every part of that institution, or every instance of that policy's or rule's application";
} 
This, however, is precisely how the ACM's choice position also operates. Parties there do not attempt to balance self-interest against reciprocity. Once in the choice position, parties are assumed to be motivated by rational self-interest alone. ${ }^{125}$ It is the construction of the choice position which ensures that the self-interest of each party would be channelled along the path carved out by the demands of reciprocity. ${ }^{126}$ I took pains to explain and emphasise this point:

The ACM "operationalizes [reciprocity, as well and liberty, and thus, equality] by requiring all principles to be selected from its "choice position". ${ }^{127}$

"Because of the construction of the choice position, parties must act reasonably [i.e. with reciprocity]."

Here, then, is how the ACM reconciles self-interest with reciprocity:

"Parties seek to further their self-interest in choosing the principles to govern insolvency situations, but "The state of ignorance in the [choice] position is so shaped that the antecedent interest of everyone must lie [] in the same solution." 129

Corporate Insolvency, 48; see also at 82 , including footnote 88 , and more generally, the use of what I called the distinction between 'individual-level' and 'institutional-level' justifications. This aspect of my argument did not make it into Duggan's review, and so would not have been apparent to Moreau. (2) It is of course true that Rawls's primary concern in A Theory of Justice was as suggested by Moreau. However, Rawls also noted the "flexibility of the idea of the original position [as] shown [by the fact of] its being modifiable to fit the subject in question"; see The Law of Peoples (London: Harvard University Press, 2000), 86, where the position is utilised to select principles of international justice, a use foreshadowed in $A$ Theory of Justice itself (pp. 378 et seq.). There is thus no general Rawlsian objection to applying variants of the original position at different levels of generality or specificity. (3) In particular, the ACM's choice position is a means of ensuring that any given set of legal practices can be tested as to whether it is impartial as among those it affects. Once again, there seems no general reason for thinking that doing so by using the Dramatic Ignorance heuristic is objectionable. For detailed defences of this sort of use of Rawlsian choice positions, see Corporate Insolvency, chapter 3, and also Swygert, and Yanes, "A Unified Theory of Justice: The Integration of Fairness Into Efficiency" (1998), 73 Washington LR 249, and Farber, "Economic Efficiency and the Ex Ante Perspective', in Kraus and Walt (eds.), The Jurisprudential Foundations of Corporate and Commercial Law (Cambridge: Cambridge University Press, 2000).

${ }^{125}$ See for example Corporate Insolvency, 72: "the choice position provides the non-arbitrary, morally privileged standpoint from which parties are to make calculations of antecedent self-interest." The moral desirability of endowing the parties with (inter alia) reciprocity is embedded in the construction of the choice position; once in that position, however, the parties are moved by their self-interest.

${ }^{126}$ At Corporate Insolvency, 86, I was referring to exactly this interplay between the position's structure and the parties' self-interest when I remarked (in passing, while summarising a different argument) that the parties are "motivated by antecedent self-interest and considerations of reciprocity". Duggan seizes upon this fragment as evidence that reciprocity must, in some unspecified way, be "weighted" as against selfinterest; see "Contractarianism", 470-471. But his reading is flatly inconsistent with what seems to me to be overwhelming textual evidence, some of which I present in the text here. Compare also Corporate Insolvency, 3-4 and 8, where the discussion concerns the ACM's characterisation of the parties in the real world, rather than in the model's choice position. This distinction too is based on Rawls.

${ }^{127}$ Corporate Insolvency, 28.

${ }^{128}$ Ibid., 76 (emphasis added).

${ }^{129}$ Ibid., 77, quoting Dworkin, "Position", 49. See also Corporate Insolvency, 81, including footnote 84. 
It should be clear, then, that the choice position does not require the parties to strike some sort of balance between reciprocity and self-interest. In fact, reciprocity is ensured here even as the parties go about making calculations of self-interest:

"Since the parties do not know who they will turn out to be once the state of Dramatic Ignorance is removed, they must equally take into account the interests of all the actual people they might find themselves to be." 130

\section{The Automatic Stay}

The automatic stay in corporate liquidation obviously affects the interests of all (in the UK, unsecured $^{131}$ ) creditors. In the ACM's choice position, the parties would, firstly, recognise, for the reasons described above, the desirability of minimising duplicative monitoring, dealing with risk aversion, preserving any going concern surplus, and eliminating the need to strike real-life ex ante bargains. These factors all argue in favour of the abandonment of the individualistic preinsolvency regime in favour of a collective one characterised by the automatic stay. This by itself would not satisfy the parties in the choice position, however. They anticipate turning out to be, or to have their interests represented by, systematically weak or systematically strong creditors, inter alia. The parties must therefore satisfy themselves that the stay does not unduly disadvantage either group.

Secondly, then, the stay seems to protect the interests of parties (especially one-off transactors) who as a group simply would not have any chance of competing against repeat players in the individualistic race, and (for non-consensual creditors or those in a weak bargaining position) might have had little control over the terms of the loan. Further, certain creditors might be vulnerable to serious harm if provided too small a return on their loan in their debtor's insolvency. Such creditors arguably deserve greater ex post protection in the insolvency forum than creditors able to protect themselves ex ante, for example, through diversification. The parties in the choice position accept, however, that such protection could be provided within the collective regime marked by the automatic stay, for example, by according a higher priority to the claims of such creditors.

Thirdly, the parties in the choice position know that the creditors worst affected by the automatic stay (creditors who are not risk averse in any particular transaction because they are repeat players, and those having insider knowledge of the company's prospects, etc.) have the ability to diversify, or to adjust interest rates and other terms of the loan to compensate for the effects of the stay, or both. This assures them that such creditors would not suffer harm to their vital interests if they are indeed subjected to the collective regime.

The automatic stay also affects the debtor's shareholders, suspending any claims they might have against the company. The parties in the choice position realise, however, that the automatic stay is likely to maximise the value in the debtor's estate for the reasons already considered, and that this is in the shareholders' interest as maximising the chance of their receiving any potential surplus. In addition, parties in the choice position would also deduce that

\footnotetext{
${ }^{130}$ Ibid., 83.

131 There would appear to be no justification whatsoever for the immunity from participation in the collective liquidation regime conferred by English law on secured creditors. For precisely the sorts of reasons considered in the text here, the enforcement of secured claims should be stayed in liquidation, as it is in the UK administration procedure, which often performs exactly the same substantive functions as a well-run liquidation.
} 
a collective liquidation regime minimises the uncertainty inherent in any individualistic postinsolvency regime about the creditors' respective positions in the queue for the debtor's assets. ${ }^{132}$ This would be reflected in the interest charged by adjusting creditors on their loans during the company's solvency. Since the company would have to pay less on financing its debts, more would be available for disbursement to the shareholders. Realising this, each party in the choice position would be willing to accept the automatic stay even though they might turn out to be (or be represented by) a shareholder of the company rather than a creditor.

\section{THE PARI PASSU PRINCIPLE AND THE DISTRIBUTION OF THE INSOLVENT ESTATE}

I have argued that significant confusion besets discussions of the pari passu principle in the judgments of (at least English) courts and in academic commentary. ${ }^{133}$ It is essential to distinguish three principles, all of which are sometimes referred to as the pari passu principle.

\section{A. The Pari Passu Principle Identified}

Firstly, there is the pari passu principle properly so called ('the pari passu principle'). ${ }^{134}$ This principle requires insolvency law to take claimants "exactly as it finds them", ${ }^{135}$ such that the distribution of assets within an insolvency forum is based on the pre-insolvency form of claims. So for example, all those holding claims classified under pre-insolvency law as 'unsecured' ought to be repaid the same proportion of their claims as all others similarly placed. On this understanding of the pari passu principle, the existence of insolvency set-off and preferential claims (among others) constitutes exceptions to this principle.

Secondly, sometimes the term 'pari passu' is also confusingly used to refer to pro rata distribution within the various classes of claimant established by insolvency law itself ('the principle of ratable distribution within classes'). ${ }^{136}$ It should be clear why it would be extremely confusing to describe this too as pari passu distribution: the ratable treatment of preferential claims inter se constitutes the application of this principle, whereas the very existence of preferential claims constitutes an exception to the pari passu principle, properly understood in the first sense described above. It would be paradoxical - indeed, self-contradictory - to say that the treatment of preferential claims is an application of, and yet the very existence of such claims is an exception to, one and the same pari passu principle.

Thirdly, confusion is compounded when the term 'pari passu' is used to describe not just one or both of the above situations, but also to refer to the automatic stay. ${ }^{137}$ While the two

\footnotetext{
132 Jay Westbrook, "The globalisation of insolvency reform" [1999] New Zealand LR 401, 406-7.

133 Corporate Insolvency, chapter 4, particularly 94-95 and 102-106; see also Mokal and Look Chan Ho, "The Pari Passu Principle in English Ancillary Proceedings: Re Home Insurance Company" (2005) 21(6) Insolvency Law and Practice 207.

${ }^{134}$ In the UK, enshrined, for example, in s. 107 of the Insolvency Act 1986 and r. 4.181(1) of the Insolvency Rules 1986.

${ }^{135}$ See for example Re Smith, Knight \& Co, ex p Ashbury (1868) LR 5 Eq 223, 226: “The Act of Parliament unquestionably says, that everybody shall be paid pari passu, but that means everybody after the windingup has commenced... [The Act] takes them exactly as it finds them, and divides the assets amongst the creditors, paying them their dividend on their debts as they then exist."

136 This principle is exemplified by s. 175(2)(a) of the UK Insolvency Act 1986, which provides that preferential claims are to rank equally among themselves and would abate in equal proportions if the company's assets are insufficient to meet them in full.

137 This is to be found in, for example, s. 130(2) of the UK Insolvency Act 1986.
} 
principles described in the previous two paragraphs are distributive (specifying how the value in the insolvent estate is to be allocated amongst various claimants), the automatic stay does not mandate distribution of any sort. It is in fact about the conservation of the insolvent estate, striking down attempts to bypass the collective insolvency regime. The automatic stay is perfectly compatible with any manner of distribution within a collective insolvency forum, be it pari passu, or ratable distribution within classes set up by insolvency law itself, or indeed any other distributive formula.

\section{B. What the Principle Does and Does not Do}

I have argued that the pari passu principle, disentangled from the principle of ratable distribution within classes and from the automatic stay, is rather less important than it is sometimes made out to be. Firstly, both empirical evidence ${ }^{138}$ and doctrinal arguments ${ }^{139}$ demonstrate that the principle does not constitute an accurate description of how the assets of insolvent companies are in fact distributed (here, the principle of ratable distribution within classes is more important). Second, the principle has no role to play in ensuring an orderly winding-up of such companies (this is the role of the automatic stay and other aspects of the collectivity of the insolvency regime). Thirdly, the pari passu principle does not underlie, explain or justify distinctive features of the formal insolvency regime, notably, its collectivity (which, as mentioned above, is about the conservation of the insolvent estate, not about its distribution). Fourth, most of the (English) case law said to support the pari passu principle actually supports the principle of ratable distribution within classes, or the principles underlying or bolstering the automatic stay, or both. What such case law does not support is the pari passu principle properly so called. Fifth and finally, in the distribution of value from the insolvency estate, fairness more often demands the rejection than the application of the principle. This is discussed in the following sub-section.

What, then, is the true role of the pari passu principle? I argued that it operates as a 'fallback' mechanism, which takes over when it would be pointless and thus wasteful to provide any other distributive method. Insolvency law creates or tolerates particular distributive rules to govern those types of claim that the policy of the law requires to be met to the extent possible (for example, some claims held by employees, who enjoy a statutory preferential status, or those held by certain secured creditors). But once this is done, nothing (or not much) would be left for distribution to other creditors. Most insolvency proceedings (in England, 75\% of them or more) yield nothing for general unsecured creditors. And when they do bring some returns, the yields are fairly small (about 7 pence on the pound on average in all proceedings). So there simply is no point in deciding how these claims should rank vis-à-vis each other. For such claims to be governed by the pari passu rule makes very good sense, since the costs in terms of time, effort, and resources required to determine their appropriate (fair and efficient) rankings would far exceed any benefits. For such a situation, in fact, the superficial equality of the pari passu principle is ideal. In most instances, this simply means some types of creditor equally get nothing.

\footnotetext{
${ }^{138}$ Which is unequivocal: most of the external funding for small to medium sized enterprises comes from creditors who can assert proprietary rights (be they security interests or retention of title) in the event of the debtor's insolvency, and who are thus beyond the ambit of the pari passu principle. Similarly, in an overwhelming majority of formal insolvency proceedings, nothing is distributed to general unsecured creditors, i.e., to the parties who are subject to the pari passu principle. For a detailed discussion of the empirical date, see Corporate Insolvency, pp 99-100.

${ }_{139}$ See for example Corporate Insolvency, pp 96-102. Ho, 'Pari Passu Distribution and Post-Petition Disposition: A Rationalisation of Re Tain Construction' (2003) 19 I.L.\&P. 155; Ho, 'On Pari Passu, Equality and Hotchpot in Cross-Border Insolvency' [2003] LMCLQ 95; Ho, 'The Principle against Divestiture in Insolvency Revisited: Fraser v Oystertec' [2004] JIBLR 54.
} 
In the remaining minority of insolvencies, the tiny amounts available for distribution are all distributed proportionately, rather than being wasted in ascertaining the claimants' correct rankings. The pari passu principle applies, then, whenever the costs of providing for different rankings for different claims would exceed the benefits. ${ }^{140}$ The claims it governs mostly - and necessarily - constitute something approaching a distributively null set: they are held by those who will receive nothing (or very little).

\section{Insolvency Distribution to Vulnerable Creditors}

Within the ACM, what sort of factors might justify according distributive priority to some types of creditors over others? Duggan provides an excellent summary: ${ }^{141}$

"in terms of the ACM, equality does not mean formal equality but, rather, 'a right to equal concern and respect in the design and construction of institutions'. In the ACM['s] choice position, parties bargaining about the appropriate rule for the distribution of the insolvent's assets would not choose an across-the-board pari passu rule. Creditors are not homogenous. For example, banks are well diversified (because they lend to many debtors), good risk-bearers (because they can spread their losses from any given insolvency [and, I would add, because they exercise very great control over the terms on which they lend] and knowledgeable about the risks of lending (because they are repeat players in the market for the provision of credit). The ACM's assumption of Dramatic Ignorance means that parties in the choice position do not know whether they would turn out to be bank-creditors or employee-creditors and 'so they accord equal concern to the sets of interests associated with each. But this requires that those in a more vulnerable position in their debtor's insolvency be given greater protection than those better able to deal with the loss. [Knowing that they could deal quite well with being paid back less on any individual loan if they turned out to be represented in the real world by a bank, all] the parties [might] agree to provide greater protection to employee-claimants, just in case they find themselves vulnerable to great harm as one themselves."

But what about the CBM? Duggan suggests that there are "at least two possible ways of accounting for the preferential treatment of employee wage claims using the CBM model."142 The first, the contract-failure explanation, suggests that if able to negotiate costlessly and with sufficient information, employees would bargain for a risk premium as part of their wage package to cover the risk of non-payment in their employer's insolvency. Crucially, it is "in the other creditors' interests to agree [to this premium], because ex ante they would worry that otherwise employers might have trouble attracting labour." 143 The statutory preferential payment regime for certain employee claims merely replicates the terms of this hypothetical bargain. On the second view, the risk-shifting explanation, employees are worse risk bearers than other types of creditor since they are unable to diversify, and since they might not have the resources, knowledge or experience to monitor the debtor and to adjust the terms of their loans accordingly. In the ex ante

${ }^{140}$ This point is explained in somewhat different terms in Mokal, "On Fairness and Efficiency" (2003) 66(3) MLR 452, 459.

141 "Contractarianism", 473 (citations to Corporate Insolvency omitted; some minor amendments).

${ }^{142}$ Ibid., 473-474, citing Kevin Davis and Jacob Ziegel, Assessing the Economic Impact of a New Priority Scheme for Unpaid Wage Earners and Suppliers of Goods and Services (unpublished, 30 April 1998), excerpted in Ziegel, Duggan and Thomas Telfer, Canadian Bankruptcy and Insolvency Law: Cases, Text and Materials (Toronto: Emond Montgomery, 2003), 381-382. I discuss these arguments solely as Duggan reports them.

143 "Contractarianism", 474. 
bargain, therefore, employee-claims would be accorded a higher priority by all creditors as a way of shifting insolvency risk from employees to other types of creditor, "because if other creditors are superior risk-bearers the end result will be to reduce the size of the risk premium the debtor has to pay." 144

None of this seems particularly convincing. Firstly and as discussed, the CBM's reasoning does not, for the reasons explained above, lead to the imposition of the collective regime marked by the automatic stay at all. It thus cannot predict or explain, let alone justify, special distributive rules to be applied within the collective forum. Each of the explanations just summarised assumes to the contrary. Each must therefore be considered congenitally defective. Second and even ignoring that, assume that creditors enjoying individualistic debt-enforcement advantages, particularly systematic ones of the sort enjoyed by experienced repeat players or those with influence over the debtor, could be persuaded to agree in some ex ante position to give these up in return for participation rights in the collective procedure. ${ }^{145}$ Well, surely they would only do so if given the assurance that the distributive rules applicable to them therein would reflect their pre-insolvency advantages. ${ }^{146}$ It is difficult to understand why institutional lenders and creditors connected with the debtor would not only not demand this preferential status, but would go even further by accepting a position subordinate to those (like employees) with whom they have no real need to bargain for a collective regime in the first place, and whom they would systematically beat in all realistic enforcement scenarios governed by the general non-insolvency law. This objection also applies equally to both explanations proffered by Duggan. ${ }^{147}$

Thirdly and particularly in relation to the contract-failure explanation, what creditors could credibly demand in the ex ante negotiations depends, inter alia, on what the bargaining theory literature refers to as their 'outside options' (roughly, what they would do if the bargain were not to be struck). ${ }^{148}$ In the CBM, the outside option is the continuation of the individualistic regime. ${ }^{149}$ If no bargain is struck with employee-creditors, therefore, it is not that employees would cease being employees, thus causing employers to "have trouble attracting labour". Rather, they would continue being employees governed by the first-come, first-served general law. Fourthly and related to this, it is utterly implausible that all types of employees would be able credibly to threaten to withhold their labour unless promised a preferential position in their employer's insolvency. ${ }^{150}$ What would the outside option be, in particular, for employees

\footnotetext{
${ }^{144} \mathrm{Ibid}$. It is not entirely clear why, in this context, all the creditors equally would wish to reduce the aggregate risk premium on the debtor's loans. One possibility is that the lower this premium, the lower the debtor's gearing, the lower therefore the risk of the debtor's insolvency, and in turn, the greater the expected value of each creditor's claim against it.

${ }^{145}$ The implications of this assumption are traced in Corporate Insolvency, 53-54.

${ }^{146}$ See also the discussion in the following sub-section of the opposition in much CBM scholarship to 'redsitribution'.

${ }^{147}$ In "Contractarianism", 473, footnote 45, Duggan appears to imply that the CBM's explanation of the pari passu principle, that it "reflects the odds of unsecured creditors getting the money if there were no collective insolvency proceeding", is similar to mine. In fact, as should be obvious, the two explanations are diametrically opposed: as I have just argued, if creditors were to be paid within the collective regime in a manner consistent with their pre-insolvency debt-enforcement capacities relative to other creditors, the governing distributive rule would be anything but pari passu. And within the ACM, pari passu is more accurately seen as a rule of non-distribution in the sense explained above, rather than one of distribution.

${ }^{148}$ See for example Jon Elster, The Cement of Society (New York: Cambridge University Press, 1989), 7494, discussed in Corporate Insolvency, 53-54, footnote 87.

${ }^{149}$ See again for example Jackson and Scott, "Nature", 160.

${ }^{150}$ For the way in which the ACM treats differences amongst employees, see Corporate Insolvency, 125126, including footnote 164 .
} 
providing more or less fungible services? Working for another employer? But there is no reason to believe this employer's other creditors (particularly repeat-paying ones and those having influence over this employer) would have a different incentive set. Or going without work altogether? But the more vulnerable the worker, the greater (presumably) his need for work, and correspondingly, the less credible his threat to withhold services. Paradoxically, therefore, the more vulnerable an employee and thus the greater the necessity for him that his interests be protected within the collective forum, the less likely he would be within this alleged extension to the CBM to be able to bargain for it.

Finally and taking the two explanations together, notice how each of them renders the other untenable. Duggan observes that:

"The contract-failure explanation assumes that employees in real life are incapable of bargaining for a risk premium. This may not be true of employees with union representation and so the choice between the contract-failure explanation and the riskshifting explanation may turn on an empirical judgment about represented and unrepresented employees' bargaining power.",

Take that sub-set of formal insolvency proceedings in which both represented employees (that is, those able to bargain for a risk premium) and unrepresented ones (that is, those unable to charge a risk premium) have a stake. In the real world, both types of creditor are accorded a statutory preferential status. It should be clear from what Duggan says, however, that according to the contract-failure explanation, represented employees ought not to be given a preferential status, since they would already have charged a risk premium, and so would be overcompensated by the statutory priority! Correspondingly, according to the risk-shifting explanation, unrepresented employees should not be given a statutory preference, since to do so would be to violate the rights, pursuant to the hypothetical ex ante agreement, of all other types of creditor! ${ }^{152}$ Given the mutual inconsistency of these two explanations, it follows that it would be logically incoherent to accept, at one and the same time, both of them. It follows also that anyone tempted to accept either one of the two explanations would be unable to explain why both represented and unrepresented employees are equally accorded a statutory preferential status. This shows that neither of these alleged extensions to the CBM has the resources to explain the present contours of the law.

\section{THE WRONGFUL TRADING PROVISIONS}

\section{A. The Objections to Redistribution}

An important theme in the CBM literature pertains to the undesirability for insolvency law to be 'redistributive'. ${ }^{153}$ Insolvency law is redistributive in the relevant sense if and to the extent to which it alters the relative values of the pre-insolvency rights held by the various parties, most obviously, by vesting new rights in some which they do not have under the general law. The CBM's progenitors argue that creditors would have struck their hypothetical bargain, in the way outlined in section 3(a) above, only so as to deal with deployment issues, that is, those relating to the best method for preserving and maximising the value in the distressed company's estate.

\footnotetext{
151 “Contractarianism”, 474.

${ }^{152}$ Unrepresented employee-creditors would receive more because of the statutory preference than they would have been able to bargain for, and thus, all other creditors would receive less.

${ }^{153}$ See for example Jackson, Logic, 22, 24-29, 33-35, 93, etc.; Douglas Baird, "Loss Distribution, Forum Shopping, and Bankruptcy: A reply to Warren" (1987) 54 Univ. of Chicago LR 815, 817-818 and 825-826.
} 
There is therefore no warrant for insolvency law to deal with distribution issues, that is, those relating to the way in which this value is to be allocated amongst various types of claimants. It is not simply the case, claim the CBM's progenitors, that attempting to address distribution issues would place insolvency law beyond the justificatory ambit of the CBM. Further and damagingly, redistribution would create perverse incentives (in the terminology introduced in section 2(c) above, motivation costs), for those who benefit from the redistribution inoptimally to rush the debtor into the insolvency forum, and for those who would lose out under the redistribution inoptimally to impede the initiation of insolvency proceedings.

I have argued that the wrongful trading provisions, to be found in section 214 of the UK Insolvency Act 1986, are redistributive in the relevant sense. ${ }^{154}$ These provisions require the managers of a company with no reasonable prospects of avoiding insolvent liquidation to take, on pain of personal liability, every reasonable step to minimise further loss to the company's creditors. Their redistributive nature is obvious. Firstly, the insolvent firm's general creditors are given the benefit of a right, held and exercised in their favour by the liquidator, which does not exist under non-insolvency law, and they gain access under that right to the personal assets of the debtor company's directors, which assets were immune to their claims before the debtor entered the special insolvency forum. Secondly, the duty imposed by this section on directors is different from any that exists under the general law, since it is terminal in nature, aimed not at the continuation of the company in the medium to long term but with ensuring a value-maximising end to its activities in the short to (very rarely) medium term. Thirdly, the wrongful trading provisions actually upset the relative values of the rights of unsecured creditors on the one hand and the debtor's directors on the other. They protect the creditors from further loss beyond the point where the debtor is irremediably distressed, but only by removing from the directors the benefit of limited liability. Fourth and finally, these provisions are unconcerned with the relative values inter se of the rights of unsecured creditors.

Having established that the wrongful trading provisions are redistributive in the relevant sense, I went on to argue that they nevertheless do not create any perverse incentives. ${ }^{155}$ Firstly, they do not encourage general creditors, the beneficiaries of the redistributive effect, to rush the debtor into the insolvency forum with undue haste, since the quantum of the benefit they would thus receive would be no more than the loss that they could be established to have suffered because of the inappropriate response by the debtor's directors to its irremediable distress. ${ }^{156}$ And secondly, the debtor's directors not only do not get an incentive to keep the debtor out of the insolvency forum, they in fact acquire a reason to determine the optimal time at which the debtor ought to be consigned to this forum, and then to put it there. If they do not, then their personal assets are liable to being made available to general creditors to the extent to which the latter have suffered loss resulting from the undue delay on the directors' part. ${ }^{157}$

The fact that the wrongful trading provisions do not create incentives for strategic misuse of the insolvency process despite being redistributive does not, in and of itself, lead to the

\footnotetext{
${ }^{154}$ Corporate Insolvency, 269-273. What follows here is a greatly abbreviated summary.

155 Corporate Insolvency, 295-302. Again, what follows is a simplified summary. Note in particular the treatment of the 'punishment effect' at 296-299, which is not discussed here.

${ }^{156}$ Duggan, "Contractarianism", 478, might have missed this part of my argument, since he asserts part of my conclusion without attributing it to me, and as if it were an objection to my position.

${ }^{157}$ Duggan notices this argument at "Contractarianism", 478.
} 
conclusion that the CBM cannot explain these provisions. ${ }^{158}$ It is nevertheless clear that these provisions fall beyond this model's explanatory and justificatory ambit. ${ }^{159}$

\section{B. Wrongful Trading and the Creditors' Bargain}

How might the CBM go about attempting to explain the section 214 duty? Here is one suggestion. ${ }^{160}$ It might be said that some far-sighted creditors in some (perhaps all) real-life transactions would realise ex ante, before lending anything, that doing so would give rise to financial agency costs in case the debtor were later to become terminally distressed. In other words, the debtor's directors would strive to keep it out of the insolvency forum, hoping thereby to keep their jobs, and at least formally, to preserve the shareholders' equity interest. The creditors would suffer as a result, however, since, ex hypothesi, no reasonable prospect would remain at that point of the debtor avoiding insolvent liquidation. Attempts to stave off the (practically) inevitable would therefore result in further loss of value to the creditors as a group. Anticipating ex ante the existence of these agency problems, the creditors could contract for the right to monitor the directors, and then incur costs in doing so. However, as long as creditors anticipated the existence of these additional costs, they would take them into account in deciding what to charge on their loans to the firm. So monitoring costs would be passed on to the firm, and thus to its shareholders, its residual claimants. At the ex ante negotiations, therefore, shareholders in their turn would find it cheaper to agree with creditors that in case the debtor were to become terminally distressed, its directors should thenceforth be required to protect the interests of creditors rather than those of shareholders. In other words, whether creditors would be required to monitor directors, or directors would have to bond themselves to creditors, it would be the shareholders who would bear the costs. And shareholders would prefer the sort of bonding involved in the wrongful trading provisions over monitoring since that would be likely to be cheaper in many circumstances. On this reasoning, then, a section 214-type duty would be accepted by shareholders in a real-life ex ante bargain.

This argument does not succeed. Firstly, the wrongful trading provisions are meant to ensure that hopelessly troubled companies enter the insolvency forum at the optimal time. ${ }^{161}$ This forum enables and forces those interested in the company's undertaking to forego aggressive and value-destroying individual action. In other words, one of the functions of the collective insolvency regime is to minimise the co-ordination costs of the creditors of a firm threatened with insolvency. Section 214 is a tool enabling the regime to take over when these costs would be most acute. However, the existence of the collective regime might itself create motivation costs by producing incentives for parties who would lose out under it to try to prevent the company

158 Contra Duggan, "Contractarianism", 477: "Section 214 is inconsistent with the CBM, Mokal says, because it is a redistributive provision." In fact, in the 2000 paper to which I have already referred, I claimed that the CBM could be modified so as to drop its objection to redistribution per se; see Mokal, "Wrongful Trading". See however the arguments in the following text.

${ }^{159}$ None of the arguments to follow, drawn from chapter 8 of Corporate Insolvency, is adverted to by Duggan. Instead, he observes, at "Contractarianism", 478, that "the concern in the CBM is not with provisions that are redistributive per se but, rather, with redistributive provisions that create incentives for individual players to hasten or delay the debtor's liquidation...[And] while it may be true to say that s. 214 changes relative entitlements, it is not at all clear that the provision encourages opportunism." In Corporate Insolvency, 304, I anticipated this response (which is also given by Jackson himself). But for the reasons to be pointed out here, neither this nor Duggan's second response to me, starting on "Contractarianism", 478, go to what is really at issue.

${ }_{160}$ Drawn from Mokal, "Wrongful Trading".

${ }^{161}$ Either through the invocation of a formal insolvency proceeding by the directors, or more generally, by realigning their own duties towards protecting the interests of the company's creditors as a group. 
becoming subject to it. Directors would act for themselves (out of fear of losing their jobs upon the initiation of liquidation) and on behalf of shareholders (who would formally lose their equity interest when the company goes into insolvent liquidation) to keep the firm out of the insolvency forum. Against this background, the main role of section 214 is to assist in overcoming the coordination costs of creditors by controlling creditor/manager agency costs on the eve of insolvent liquidation. This shows why the CBM is unlikely to be able to account for this section: As already explained, the most plausible prediction emerging from this model is that there would be no switch-over from an individualistic to a collective regime. Since the wrongful trading provisions are a means of buttressing the collective liquidation regime, therefore, they too cannot be explained through the CBM. ${ }^{162}$

Secondly and even ignoring this fundamental problem, not all types of creditors who are Real Parties in Natural Ignorance are able to anticipate the motivation costs of managers on the eve of their firm's insolvency. So for example, one-off transactors like employees (who are not in the business of making loans, and therefore, of making loans to companies which become insolvent) and some inexperienced trade creditors, might be in this position. Further and more importantly, regardless of whether all creditors anticipate (or ought reasonably to anticipate) the existence of this type of motivation costs, not all of them would be in a position, while negotiating with creditors and shareholders in some ex ante position, to pass them on to the debtor's shareholders. Whether they could do so would depend on their bargaining power vis-àvis that of the shareholders, and there is no reason to think that this would always be such as to ensure that all or most of the monitoring costs were borne by shareholders. What is more, to the extent that some creditors are non-adjusting and do not take monitoring costs into account when deciding what to charge a particular debtor (the Crown, for example), the same holds for them as well. Finally, the very types of creditor most likely to be on the wrong side of a disparity of bargaining power between them and shareholders (again, for example, employees and some trade creditors) are also likely to be intrinsically poor monitors, ill-equipped to gather or demand information about the debtor's activities, and unable to respond to any such information in any case (e.g. by bringing pressure to bear on the debtor's management sufficient to make it desist from misbehaviour).

Taken together, these observations lead to the conclusion that some types of creditor, by threatening to pass on relatively higher monitoring costs to shareholders, would be able to get agreement from them to relatively lower-cost bonds against eve-of-insolvency misbehaviour on the management's part. But these bonds would not be general, seeking to protect the interests of all creditors. Instead, they would be specific, aimed at protecting from misbehaviour only those creditors who could otherwise load on to shareholders the costs of monitoring the debtor. ${ }^{163}$ So this line of argument provides no reason for thinking that the inclusive section 214 duty, which seeks to encourage managers of a firm on the brink of insolvency to take every (reasonable) step to minimise harm to all of the firm's creditors - seeks, in other words, to subordinate the interests of the debtor's managers and shareholders to the interests of all creditors, not just those able to load monitoring costs onto shareholders - would be acceptable to the debtor's shareholders. It therefore provides no justification for that duty.

\section{Justifying the Wrongful Trading Provisions}

For the reasons outlined above, the ACM does predict and justify the collective regime marked by the automatic stay. We can therefore ask if it can also help us analyse the wrongful trading

\footnotetext{
162 See Corporate Insolvency, 265, footnote 14.

${ }^{163}$ Most likely, these bonds would take the form of security; Corporate Insolvency, 293-295.
} 
provisions, which aim to ensure that the collective regime would take over at the right point in time during the debtor's terminal distress.

In the ACM's choice position and having been placed in Dramatic Ignorance, the parties do not know whether they would turn out to be the shareholders, the creditors, or the directors of the firm on the brink of insolvency. So they must equally take into account the interests of all these parties. To start with, and even knowing that some of them would turn out to be the debtor's shareholders, all the parties would conclude that, once there remained no reasonable prospect of the firm avoiding insolvent liquidation, directors' efforts, on the shareholders' behalf, to strive unreasonably to reverse the firm's fortunes would be harmful to them all, taken as a group, in the ways described above. Being rational, they would seek to minimise these motivation costs, and for the same reason, would seek to do so in the cheapest way possible. It has already been noted that it would generally be less expensive to seek bonds against misbehaviour from managers than to monitor them directly. ${ }^{164}$ Parties bargaining in the choice position know, however, that in the real world, some of them would not be able to anticipate the need to monitor, and in addition, may not be able to get the shareholders' approval to directors giving those bonds (for the reasons already discussed). This would be unacceptable to the bargaining parties for two reasons. First, to the extent that monitoring is more expensive than bonding, it would be irrational to tolerate the possibility that some creditors - unable to compel shareholders to agree to the directors providing such bonds - would have to monitor nevertheless. Parties in the choice position would wish to avoid these deadweight costs. And second, parties would seek to be protected against directors' misbehaviour even if they turned out to be the sort of creditors not only unable to compel shareholders to allow directors to offer bonds to them, but also unable efficaciously to monitor directors themselves.

For both these reasons, it would be acceptable to all the parties treated as equals for an inclusive bond in the creditors' favour to be extracted from the directors. In the choice position, each party would have an equal incentive to provide that, on the eve of insolvent liquidation, the firm's managers should be required to switch allegiances, coming under obligations to act so as to prevent harm to all of the firm's creditors as a group. This, I argued, provides justification for the section 214 duty.

\section{CONCLUSION}

If and to the extent to which the foregoing arguments are valid, Duggan fails to inject plausibility into the Creditors' Bargain Model. The CBM is at best indeterminate, providing no specific point in time at which to ascertain the creditors' self-interest, no reason to think that creditors should be taken to have consented to rules and principles that reflect their self-interest at any particular point, and no basis for concluding that the essential collectivity of insolvency law is equally in the interests of all types of creditor. What is more, the CBM mistakenly assumes Kaldor-Hicks, or perhaps Pareto, efficiency to be normative ideals by which to judge insolvency law, when in fact each of these versions of efficiency is unattainable in practice, question-begging because susceptible to wealth effects, and normatively defective. Duggan's own suggestion, that the CBM can be rescued by taking its ex ante position as referring to a time at which no insolvency laws have been enacted, provides no solution to any of these fundamental problems. What is more, this suggestion leaves mysterious what Duggan takes to be the alternative: how could the ex ante

${ }^{164}$ The parties would acknowledge the desirability of these bonds even though some of them would turn out in the real world to be the directors thus bonded, as long as the obligations imposed on directors through these bonds were clear in advance and did not require of them guarantees they could not reasonably provide. 
position be based on anything but the assumption that no insolvency law exists at the time that the hypothetical bargain is to be struck?

A better approach, it was argued, is to recognise the distinction between substantive and procedural legal goals, and to reject both Pareto and Kaldor-Hicks as incapable of serving as either type of goal. Insolvency law is best conceptualised as having as its substantive goal the provision of a fair scheme of co-operation as equals amongst all those affected by peculiar insolvency issues. Its main procedural goal is the pursuit of transaction cost efficiency, which aims to minimise the sum of co-ordination and motivation costs. The Authentic Consent Model, which enshrines these premises, successfully explains and justifies not only the collectivity of the insolvency law, but also the nature and proper place of the pari passu principle and the UK wrongful trading provisions. 